\title{
Analyzing consolidation data to predict smear zone characteristics induced by vertical drain installation for soft soil improvement
}

\author{
Ali Parsa-Pajouh ${ }^{1}$, Behzad Fatahi ${ }^{* 1}$, Philippe Vincent ${ }^{2}$ and Hadi Khabbaz ${ }^{1}$ \\ ${ }^{1}$ School of Civil and Environmental Engineering, University of Technology Sydney, Sydney, Australia \\ ${ }^{2}$ Menard Bachy Pty Ltd., Sydney, Australia
}

(Received December 18, 2013, Revised March 06, 2014, Accepted March 17, 2014)

\begin{abstract}
In this paper, the effects of variability of smear zone characteristics induced by installation of prefabricated vertical drains on the preloading design are investigated employing analytical and numerical approaches. Conventional radial consolidation theory has been adopted to conduct analytical parametric studies considering variations of smear zone permeability and extent. FLAC 2D finite difference software has been employed to conduct the numerical simulations. The finite difference analyses have been verified using three case studies including two embankments and a large-scale laboratory consolidometer with a central geosynthetic vertical drain. A comprehensive numerical parametric study is conducted to investigate the influence of smear zone permeability and extent on the model predictions. Furthermore, the construction of the trial embankment is recommended as a reliable solution to estimate accurate smear zone properties and minimise the post construction settlement. A back-calculation procedure is employed to determine the minimum required waiting time after construction of the trial embankment to predict the smear zone characteristics precisely. Results of this study indicate that the accurate smear zone permeability and extent can be back-calculated when $30 \%$ degree of consolidation is obtained after construction of the trial embankment.
\end{abstract}

Keywords: prefabricated vertical drain; smear zone; trial embankment; numerical analysis; FLAC

\section{Introduction}

In the last two decades, employing prefabricated vertical drain (PVD) assisted preloading has been recognised as a very efficient ground improvement method for sites with deep soft soil deposits (Indraratna et al. 2005a, Chai et al. 2006, Abuel-Naga et al. 2006, Rowe and Taechakumthorn 2008). Installation of PVDs can reduce the preloading period significantly by decreasing the length of the drainage path, as the consolidation time is inversely proportional to the square of the drainage length (Chai et al. 2010, Walker et al. 2012, Indraratna et al. 2012).

One of the major parameters influencing the PVD assisted consolidation process and consequently the required preloading time is formation of the smear zone in the vicinity of the prefabricated vertical drains. In this study after a brief review of smear zone characteristics, the

*Corresponding author, Senior Lecturer, E-mail: behzad.fatahi@uts.edu.au 
importance of predicting accurate smear zone characteristics is numerically investigated. Several case studies are simulated using FLAC 2D and results of parametric studies are presented and discussed. Additionally, a back-analysis approach is adopted to determine the minimum required degree of consolidation after construction of the trial embankment to predict the reliable smear zone properties, which can convert the construction of trial embankment to an accurate and efficient solution for determination of disturbed soil characteristics.

\section{Smearing effect}

There are some factors such as equivalent diameter, apparent opening size (AOS), and discharge capacity of prefabricated vertical drain, as well as smear zone that control the efficiency of geosynthetic vertical drains (Lee and Chung 2010). Installation of the prefabricated vertical drains using mandrel induces disturbance of the soil surrounding the drain, resulting in a smear zone of reduced permeability adversely affecting the consolidation process (Choo et al. 2013). Predicting the soil behavioursurrounding the drain requires an accurate estimation of the smear zone properties. Generally, two major parameters are proposed to characterise the smear zone; the permeability $\left(k_{s}\right)$, and the extent $\left(r_{s}\right)$ of the smear zone, which are illustrated in Fig. 1. Determining both the smear zone extent and its permeability is a challenging task and quite difficult to be quantified.

Generally, two main reasons and theories are proposed explaining the smear zone generation: (a) the soil remoulding concept; and (b) the reconsolidation theory. If drain wells are installed by driving cased holes which are back filled as the casing is withdrawn, driving and pulling the casing would distort and remould the adjacent soil (Barron 1948, Hansbo 1981, Indraratna and Redana 1997). According to the remoulding concept, for PVD assisted preloading design, the soil surrounding the drain is divided into two sections: (i) the disturbed region in the vicinity of the drain; and (ii) the intact or the undisturbed zone beyond the undisturbed zone. Sharma and Xiao (2000) reported that the change in the properties of the clay layer due to the mandrel insertion is brought about by a combination of reconsolidation due to dissipation of excess pore pressure and

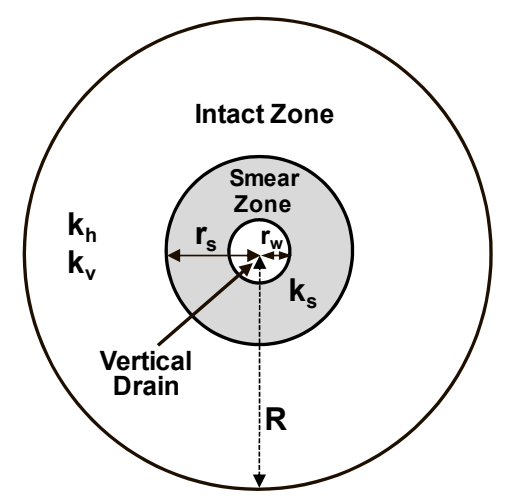

(a)

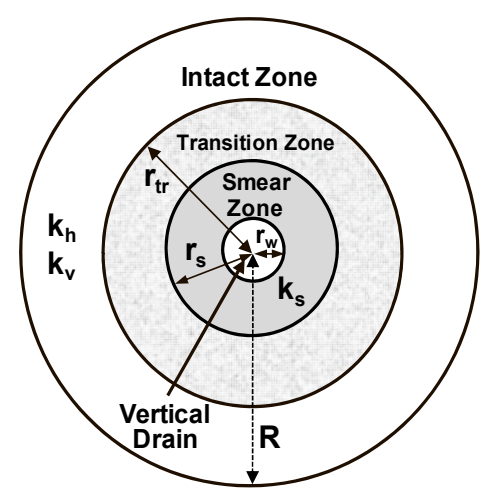

(b)

Fig. 1 Cross section of PVD surrounding by smear zone: (a) two zones hypothesis; (b) three zones hypothesis 
remoulding of the clay layer due to the shear stresses applied by the outer surface of the mandrel. In recent years, a few researchers have used the cavity expansion theory to analyse the soil reconsolidation associated with the mandrel-driven prefabricated vertical drain installation (Sathananthan et al. 2008, Ghandeharioon et al. 2010). Shin et al. (2009) used a micro-cone and an electrical resistance probe to investigate the smearing effect before and after reconsolidation.

There are two main schools of thought to determine the characteristics of the soil surrounding the drain: (a) two zones hypothesis, which divides the surrounding soil into the smear zone, and the intact zone; and (b) three zones hypothesis, considering three zones, which are the smear zone in the immediate vicinity of the drain, the transition zone, and the undisturbed zone (Figs. 1(a)-(b)). According to literature, different patterns are proposed for the permeability variation in the disturbed zone, which are summarised in Table 1.

According to literature, very diverse values are reported for the extent and the permeability of the smear zone adopting constant properties summerised in Fig. 2. The extent of smear zone $\left(r_{s}\right)$ may vary between 1.6 to 7 times of the drain radius $\left(r_{w}\right)$ or 1.5 to 6 times of mandrel equivalent radius $\left(r_{m}\right)$. Moreover, the permeability ratio $\left(k_{h} / k_{s}\right)$ may vary between 1.3 and 10 (Fig. 2).

Thus, according to the existing literature, wide ranges are proposed for the smear zone extent and permeability ratio and there is no definite method to predict the extent of smear zone and its permeability precisely to be used by practising engineers. In geotechnical practice, the

Table 1 Proposed patterns for permeability variation within the disturbed zone

\begin{tabular}{|c|c|c|c|c|}
\hline \multirow{2}{*}{ Reference } & \multirow{2}{*}{ Hypothesis } & \multicolumn{3}{|c|}{ Permeability variation } \\
\hline & & Smear zone & Transition zone & Schematic graph \\
\hline $\begin{array}{c}\text { Hansbo (1981), } \\
\text { Chai and Miura (1999) }\end{array}$ & Two zones & Constant & - & $\mathrm{F}_{0} \underbrace{\mathrm{1}_{\mathrm{f}}}_{\mathrm{r}_{\mathrm{s}} / \mathrm{k}_{\mathrm{h}}}$ \\
\hline $\begin{array}{c}\text { Walker and } \\
\text { Indraratna (2006) }\end{array}$ & Two zones & Parabolic & - & $0 \quad r_{s}$ \\
\hline $\begin{array}{c}\text { Rujikiatkamjorn } \\
\text { and Indraratna (2009) }\end{array}$ & Two zones & Linear & - & 0 \\
\hline Madhav et al. (1993) & Three zones & Constant & Linear & $\underbrace{r_{r t r} / k_{n}}_{r_{s}}$ \\
\hline $\begin{array}{c}\text { Hawlader and } \\
\text { Muhunthan (2002) }\end{array}$ & Three zones & Linear & Constant & $\mathbf{k} / \mathbf{k}_{\mathrm{h}_{\mathrm{h}}}$ \\
\hline Basu et al. (2006) & Three zones & Constant & Bilinear & $\mathrm{F}_{0}^{1} \underbrace{}_{r_{s} r_{p} r_{t r}}$ \\
\hline Basu and Prezzi (2009) & Three zones & Sigmoidal & Sigmoidal & 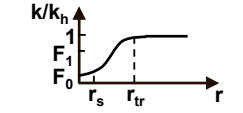 \\
\hline
\end{tabular}



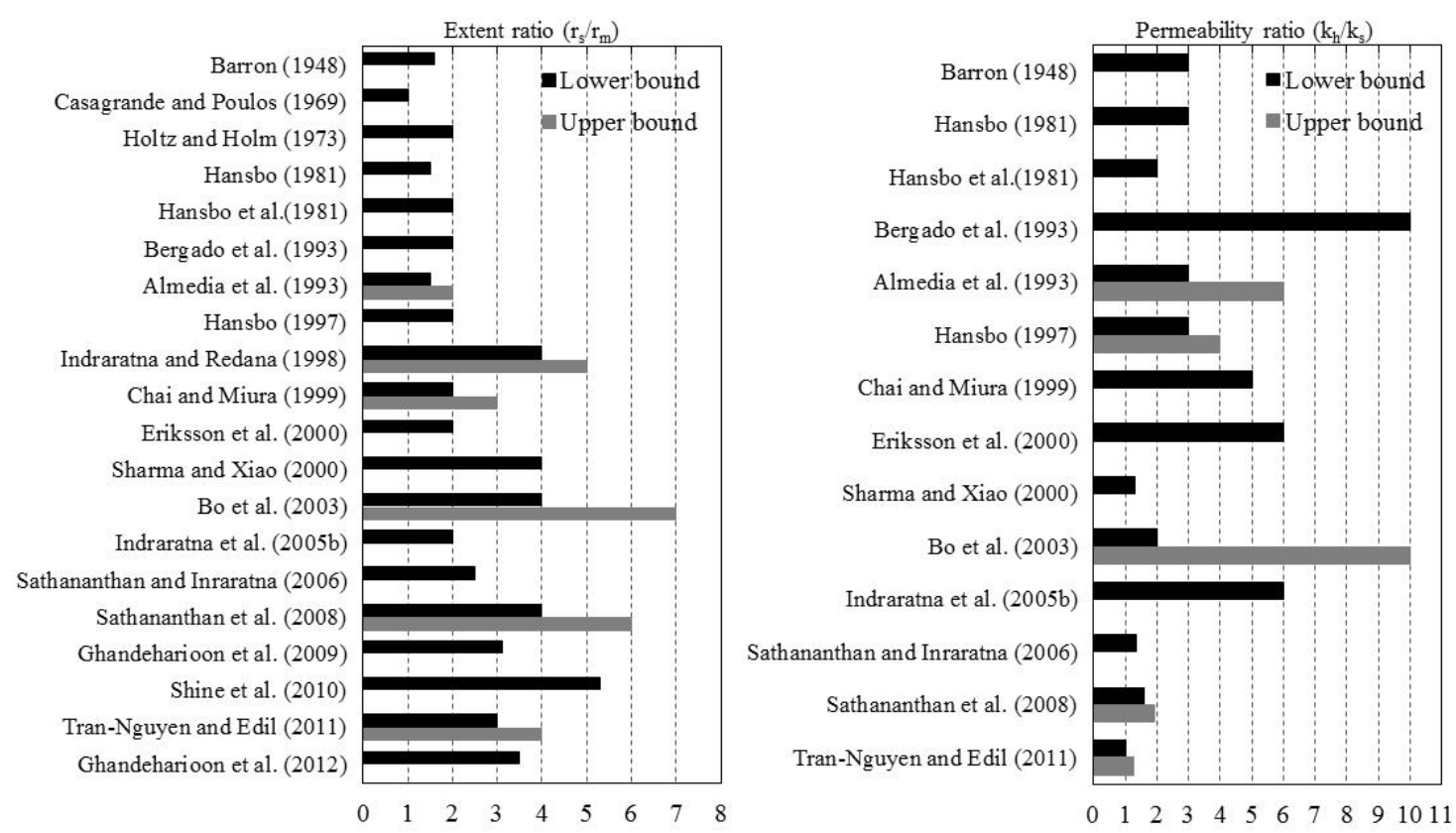

Fig. 2 Proposed values for smear zone characteristics

extent and characteristics of smear zone are estimated from the available parameter ranges which are very diverse (Fig. 2). Therefore, it is essential to study the influence of the variability in the smear zone size and its permeability on the preloading design to improve the performance of soft deposits.

\section{Simplified analytical investigation}

Barron (1948) introduced the first classical solution to estimate the radial consolidation based on the two zones hypothesis considering constant smear zone properties. A number of solutions have been developed to improve the Baron's theory for the radial consolidation (e.g., Hansbo 1981, Onoue 1988, Lo 1991). Walker and Indraratna (2006) proposed a vertical drain radial consolidation equation based on the parabolic reduction of the permeability towards the vertical drain, modifying the Hansbo's (1981) equation. Basu et al. (2006) developed analytical solutions to estimate the average degree of consolidation for the cases considering three zone hypothesis.

All the solutions can be expressed as a general form of

$$
\bar{U}_{h}=1-\exp \left(-8 c_{h} t / \mu d_{e}^{2}\right)
$$

where $\bar{U}_{h}$ is the average degree of radial consolidation, $c_{h}$ is the coefficient of horizontal consolidation, $t$ is the time of consolidation, $d_{e}$ is the diameter of the influence zone, and $\mu$ is a function related to the drain spacing, the smearing effect and the well resistance. For centre to 
centre drain spacing of $S$, the equivalent influence diameter is given by $d_{e}=1.05 \mathrm{~s}$ and $d_{e}=1.09 \mathrm{~s}$ for triangular and square patterns of drain installation, respectively.

In all classical equations, smear zone characteristics including smear zone extent and permeability ratio are the initial assumptive parameters required to calculate the degree of consolidation changing with time. The Hansbo's (1981) equation, which is being used by many researchers (e.g., Indraratna and Redana 1998, Saowapakpiboon et al. 2010, Artidteang et al. 2011, Dhar et al. 2011), has been applied in this study to investigate the effect of the current variability of smear zone properties on PVD assisted consolidation. It is assumed that the discharge capacity of the drain is large enough to ensure efficiency of the drain. According to this method, Eq. (1) can be used to calculate the consolidation time considering the following terms

$$
\begin{gathered}
\mu \approx \ln (n / s)+\left(k_{h} / k_{s}\right) \ln (s)-0.75 \\
n=R / r_{w} \\
s=r_{S} / r_{w}
\end{gathered}
$$

where, $k_{h}$ is the permeability of the intact zone in the radial direction, $k_{s}$ is the permeability of the smear zone, $R$ is the radius of the influence zone, $r_{w}$ is radius of the drain, and $r_{s}$ is the radius of the smear zone.

The required time to obtain $90 \%$ average degree of radial consolidation $\left(\bar{U}_{h}=90 \%\right)$ can be determined as follows

$$
t_{90 \%}=\left(d_{e}^{2} \cdot \mu / 8 c_{h}\right) \ln (1 /(1-0.9))
$$

To conduct parametric studies, it is assumed that the smear zone permeability ratio $\left(k_{h} / k_{s}\right)$ may vary from 1.5 to 5 , and smear zone extent $\left(r_{s} / r_{w}\right)$ range of 2 to 5 is assumed. Chittagong clay properties (adopted from Dhar et al. 2011) have been used to conduct the analytical parametric studies adopting Eq. (5). Figs. 3(a)-(b) illustrate results of parametric studies for the cases with the drain spacing of $1.5 \mathrm{~m}$ and $1.0 \mathrm{~m}$ with the square installation pattern, respectively.
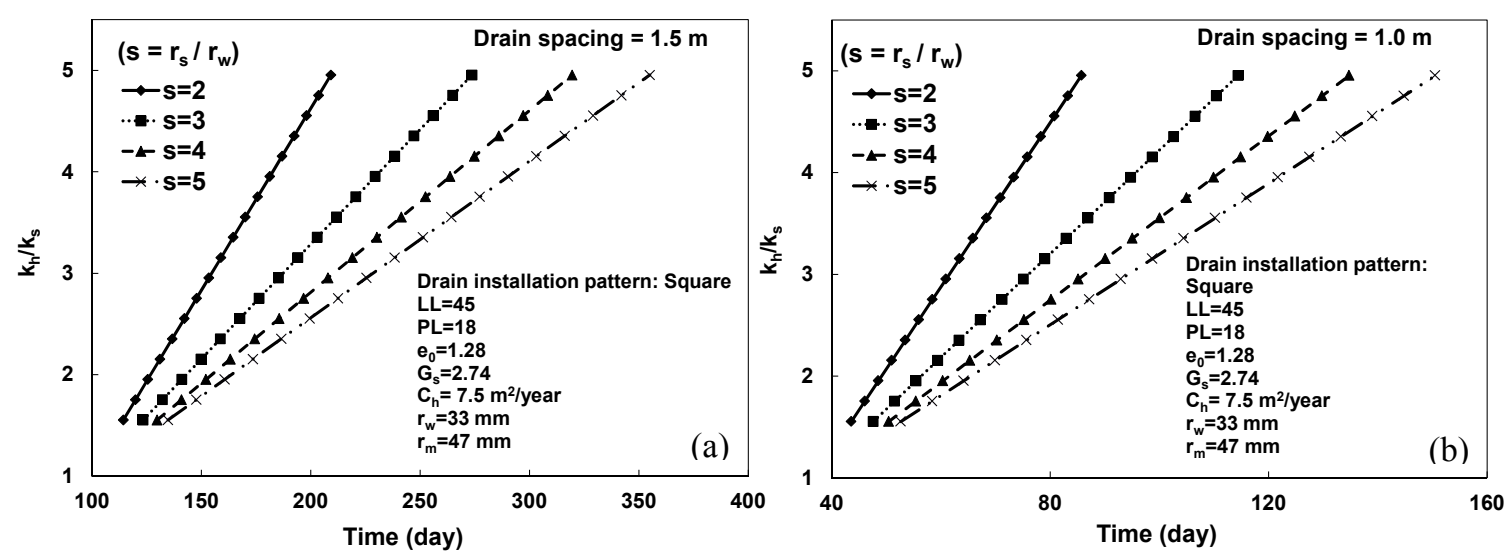

Fig. 3 Requiredtime to obtain $90 \%$ degree of radial consolidation 
According to Fig. 3, the consolidation time notably depends on the smear zone permeability, significantly influencing the preloading design. For example, assuming $r_{s} / r_{w}=2$ and the drain spacing of $1.5 \mathrm{~m}$, the required time to obtain $90 \%$ degree of consolidation are 125 days, and 210 days for $k_{h} / k_{s}$ being 2 and 5, respectively. It means that the required time to achieve $90 \%$ degree of consolidation can be increased by almost $70 \%$ while varying $k_{h} / k_{s}$ from 2 to 5 . This change is approximately $140 \%$ considering $r_{s} / r_{w}=5$. Thus, it can be observed that the variations of $r_{s} / r_{w}$, while $k_{h} / k_{s}$ is a constant number has a substantial effect on the consolidation time. The influence of the smear zone extent on the predictions is more significant when the permeability ratio is larger. For instance, changing $r_{s} / r_{w}$ from 2 to 5 considering $k_{h} / k_{s}=2$ results in a $30 \%$ increase in the consolidation time, while this change is about $70 \%$ when $k_{h} / k_{s}=5$. The combination of changes of both smear zone extent and permeability can even result in more considerable changes in the preloading time inducing major variability in the practical designs. As illustrated in Fig. 3(a), the required time to obtain $90 \%$ degree of consolidation is 355 days assuming $k_{h} / k_{s}=5$ and $r_{s} / r_{w}=5$, which is almost three times greater than the required time for the case with $k_{h} / k_{s}=2$ and $r_{s} / r_{w}=2$.

It should be noted that Eq. (1) has been originally developed to be used for a single vertical drain in axisymmetric condition and consequently, application of this equation for the vast areas with layered subsoil profile and 3D loading condition may not result in precise and reliable outcomes. Thus, a numerical code using FLAC 2D has been developed in this study to investigate the variability of PVD smear zone characteristics on the preloading design which can be used to back-calculate smear zone characteristics for actual preloading projects.

\section{Numerical modelling}

(1) According to the current literature, most of the previous numerical PVD assisted preloading simulations have been conducted using finite element codes such as CRISP (e.g., Indraratna and Redana 2000, Chai et al. 2006), ABAQUS (e.g., Indraratna et al. 2005a, b, 2008, Fatahi et al. 2009, 2012, Saowapakpiboon et al. 2011). Furthermore, PLAXIS code has been applied by a number of researchers (Arulrajah et al. 2005, Sathananthan et al. 2008, Stapelfeldt et al. 2009) for numerical simulation of PVD assisted preloading and ground improvement design. In this study, FLAC 2D has been adopted for the numerical simulation due to FLAC's capabilities to conduct systematic parametric studies and back calculation analyses essential for this research.

(2) FLAC 2D is a two-dimensional explicit finite difference program for engineering mechanics computation. In comparison to the common commercial finite element numerical modeling software, the mixed discretisation scheme developed by Marti and Cundall (1982) is used for accurate modeling of plastic deformations and flow, which is believed to be physically more justifiable than the reduce integration scheme commonly used with finite element analysis (Tabatabaifar et al. 2013a, b, Hokmabadi et al. 2014a, b). Furthermore, the employed explicit solution scheme used in FLAC in contrast to the common implicit methods can compute any material nonlinearity behaviour in almost the same computation time as a linear law, whereas implicit solution can take significantly longer to solve nonlinear problems such as fully coupled time dependent stressdeformation analysis capturing soil consolidation.

Required subroutines have been written using the built-in programming language FISH (FLACish) to tailor analyses to suit specific needs of the parametric study, giving the following 
unique advantages to the developed codes for this study: (i) customised mesh generation by entering the parameters needed to modify the grid pattern inside and outside the smear zone; (ii) considering variations in permeability with the void ratio during consolidation; (iii) ability to change different parameters such as the dimensions of the model, the properties of the vertical drain, the profile of the subsoil, characteristics of the smear zone, and the preloading conditions, while adopting customised mesh generation (essential for parametric study); (iv) integrated axisymmetric to equivalent plane-strain permeability conversion; and (v) optimising the number of mechanical and flow steps to obtain accurate numerical results while minimise the numerical calculation issues and the calculation time.

Three case studies including (a) $2.8 \mathrm{~m}$ high embankment on $11 \mathrm{~m}$ deep soft clay; (b) large laboratory consolidation with sample diameter of $0.45 \mathrm{~m}$ and central drain; and (c) $3.0 \mathrm{~m}$ high embankment on $9 \mathrm{~m}$ deep soft clay, have been selected for the numerical simulations and verification of the developed code and subroutines.

\subsection{Case study 1: Simulation of sunshine trial embankment}

A fully instrumented sunshine trial embankment has been selected as the first case study to conduct the verification process of the numerical analysis adopting FLAC. The trial embankment was constructed and monitored by the Queensland Department of Transport (1992). The equivalent plane-strain model has been employed to simulate the embankment, and the modified Cam-Clay (MCC) model has been adopted as the soil constitutive model simulating the behaviour of the soft clay. To model the prefabricated vertical drains, zero excess pore pressure boundary has been considered along the PVD. The smear zone was simulated applying undisturbed soil mechanical properties with a reduced coefficient of permeability.

In this study, a solid body is divided into a finite difference mesh consisting of quadrilateral elements in order to carry out numerical modelling. Internally, FLAC 2D sub-divides each element into two overlaid sets of constant-strain triangular elements (Fig. 4(a)). The deviatoric stress components of each triangle are maintained independently, requiring sixteen stress components to

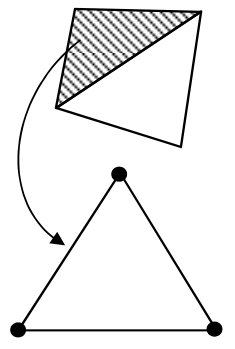

(a)

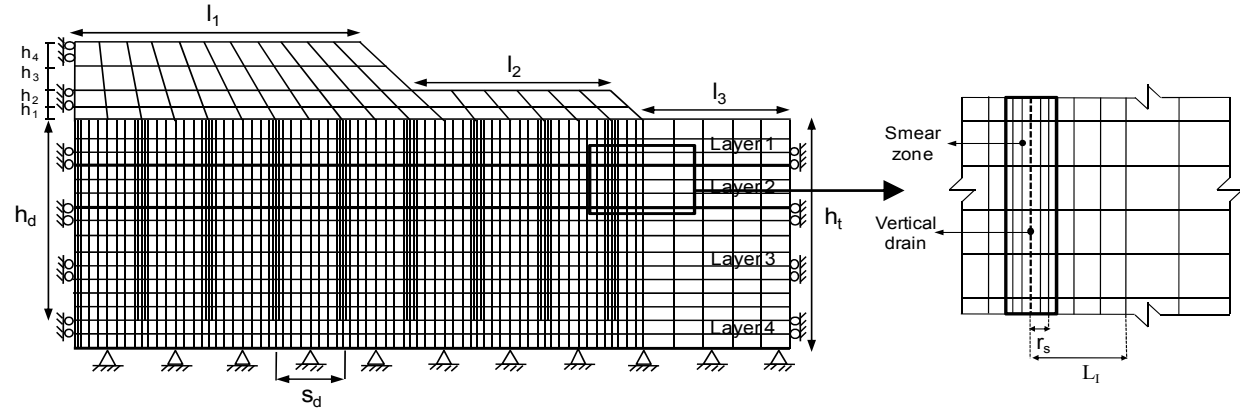

(b)

Fig. 4 Finite difference mesh: (a) FLAC 2D zone composed of overlaid triangular elements; (b) sample of grid pattern for an embankment considering the smear zone and undisturbed region ( $r_{s}=$ smear zone extent; $L_{I}=$ intact zone extent; $h_{t}=$ depth of the soil profile; and $h_{d}$ $=$ length of the vertical drain, $s_{d}=$ drain spacing) 
be stored for each quadrilateral. In the related equations, pressures and saturation values are assumed to be located at grid points (or "nodes"). Zone pressures are derived from the surroundingnodal values by simple averaging. The pore water pressure varies linearly in a triangle, assuming a uniform specific discharge in the triangle. The discharge capacity of each triangle is equal to summation of specific discharges over three sides of the triangle. This specific discharge vector contribution is then converted to scalar volumetric flow rates at the nodes. Nodal flow rates are added from the three triangles meeting at the node and are divided by two since the flow sum comes from two overlaid grids. The sample of generated mesh pattern adopting the developed code is illustrated in Fig. 4(b).

The subsoil conditions are relatively uniform throughout the site, consisting of silty/sandy clay approximately $11 \mathrm{~m}$ thick, overlying a layer of dense sand approximately $6 \mathrm{~m}$ thick. Among the available sections in this trial project, the section with the vertical drain spacing of $2 \mathrm{~m}$ has been selected. Prefabricated vertical drains (NylexFlodrain, $100 \times 4 \mathrm{~mm}^{2}$ ) were installed in a triangular pattern. A working platform $0.65 \mathrm{~m}$ thick $(500 \mathrm{~mm}$ thick drainage layer composed of $7 \mathrm{~mm}$ size

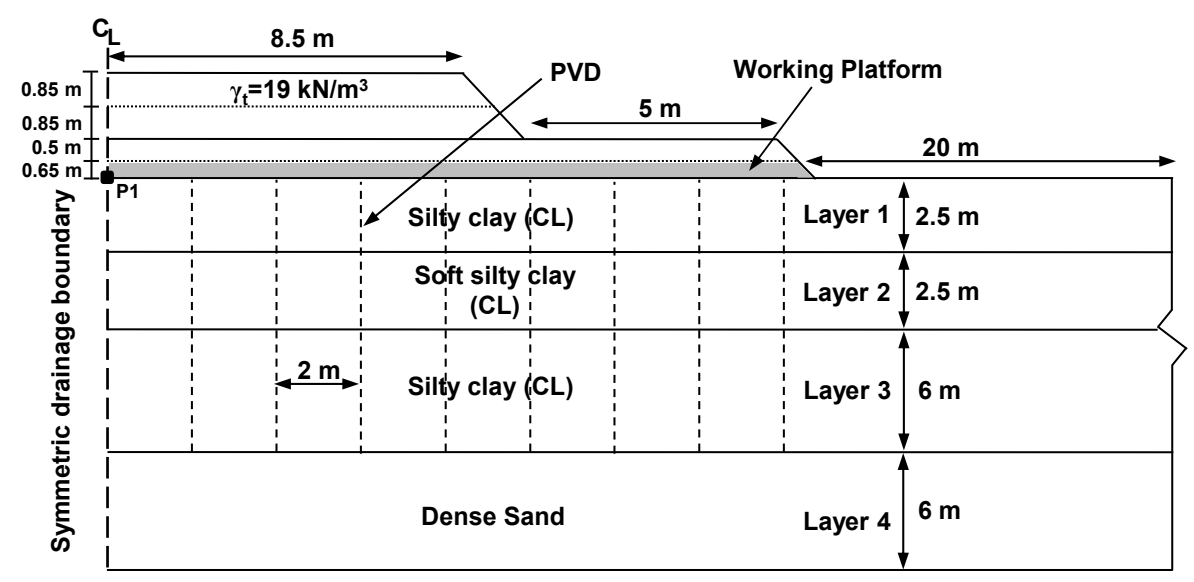

(a)

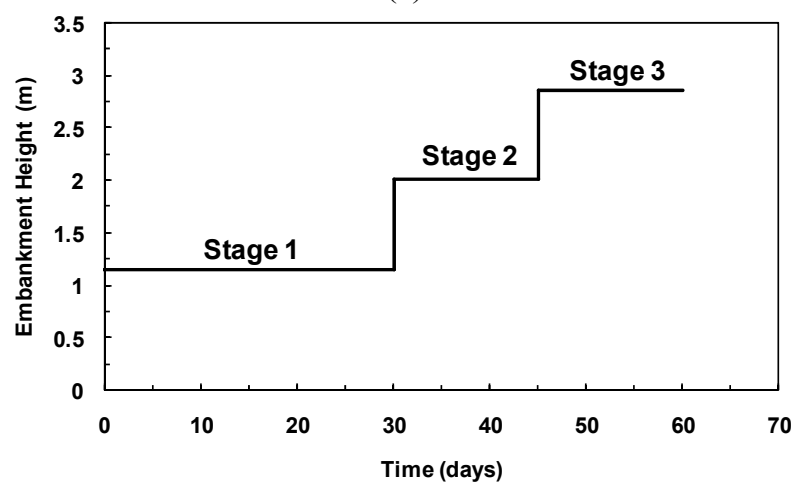

(b)

Fig. 5 Sunshine trial embankment: (a) cross section of the trial embankment and ground; (b) construction history of the trial embankment 
Table 2 Adopted properties for the numerical simulation (after Sathananthan et al. 2008)

\begin{tabular}{cccccccccc}
\hline \hline Layer & Soil type & $M$ & $\lambda$ & $\kappa$ & $v$ & $e_{\circ}$ & $\gamma_{s}\left(\mathrm{kN} / \mathrm{m}^{3}\right)$ & $k_{h p}\left(10^{-9} \mathrm{~m} / \mathrm{s}\right)$ & $k_{h} / k_{v}$ \\
\hline 1 & Silty clay & 1.20 & 0.494 & 0.0494 & 0.3 & 1.6 & 16.4 & 9.72 & 2 \\
2 & Soft silty clay & 1.20 & 2.016 & 0.2016 & 0.3 & 2.2 & 13.7 & 0.34 & 2 \\
3 & Silty clay & 1.18 & 0.532 & 0.0532 & 0.3 & 1.8 & 15.9 & 0.42 & 2 \\
\hline
\end{tabular}

Table 3 Applied properties for sand layer (after Sathananthan et al. 2008)

\begin{tabular}{cccccc}
\hline \hline Layer & Soil type & $c^{\prime}(\mathrm{kPa})$ & $\varphi^{\prime}(\mathrm{deg})$ & $E(\mathrm{MPa})$ & $v$ \\
\hline 4 & Dense Sand & 13.5 & 35 & 7.5 & 0.3 \\
\hline
\end{tabular}

gravel, plus $150 \mathrm{~mm}$ of selected fill) was placed on the natural ground surface for the construction traffic access. PVDs were installed from the working platform to the depth of $11 \mathrm{~m}$. The embankment was constructed in stages using a loosely compacted granular material $\left(\gamma_{t} \approx 19\right.$ $\mathrm{kN} / \mathrm{m}^{3}$ ) up to a height of $2.3 \mathrm{~m}$. A detailed cross section of the embankment with a selected instrumentation point is shown in Fig. 5(a). Fig. 5(b) illustrates the embankment construction history. The properties of subsurface ground profile are summarised in Tables 2-3.

It should be noted that the equivalent plane-strain permeability for PVDs analysis has been calculated using the formula proposed by Indraratna et al. (2005b), as follows

$$
\begin{gathered}
\left(k_{h p} / k_{h}\right)=\frac{0.67}{[\ln (n)-0.75]} \\
\left(k_{s p} / k_{h p}\right)=\frac{\beta}{\left(k_{h p} / k_{h}\right)\left[\ln (n / s)+\left(k_{h} / k_{S}\right) \ln (s)-0.75\right]-\alpha} \\
\alpha=\frac{2(n-s)^{3}}{3(n-1) n^{2}} \\
\beta=\frac{2(s-1)}{(n-1) n^{2}}\left[n(n-s-1)+\frac{1}{3}\left(s^{2}+s+1\right)\right]
\end{gathered}
$$

where, $k_{h}$ and $k_{h p}$ are axisymmetric and plane-strain horizontal permeability of the intact zone, respectively, $k_{s}$ and $k_{s p}$ are axisymmetric and plane-strain permeability of smear zone, respectively, $\alpha$ and $\beta$ are geometric coefficients, $n$ is the spacing ratio equal to $B / b_{w}$, and $s=r_{s} / r_{w}$. The value of $k_{h}$ needs to be determined first (laboratory or field), then $k_{h p}$ can be calculated using Eq. (6). Once $k_{h p}$ is known, the $k_{s p}$ can be obtained from Eq. (7).

The settlement gauge P1 (located on the centreline at the interface of the embankment and the ground) is selected to verify the numerical predictions against the field measurements. According to Fig. 6, FLAC results are in the best agreement with the field data assuming $k_{h} / k_{s}=4$ (permeability ratio) and $r_{s} / r_{m}=3$ (extent ratio).

Fig. 6 shows that the disparities between the numerical predictions and the field measurements are more in the initial stages of loading that could be the result of surcharge placement. For 


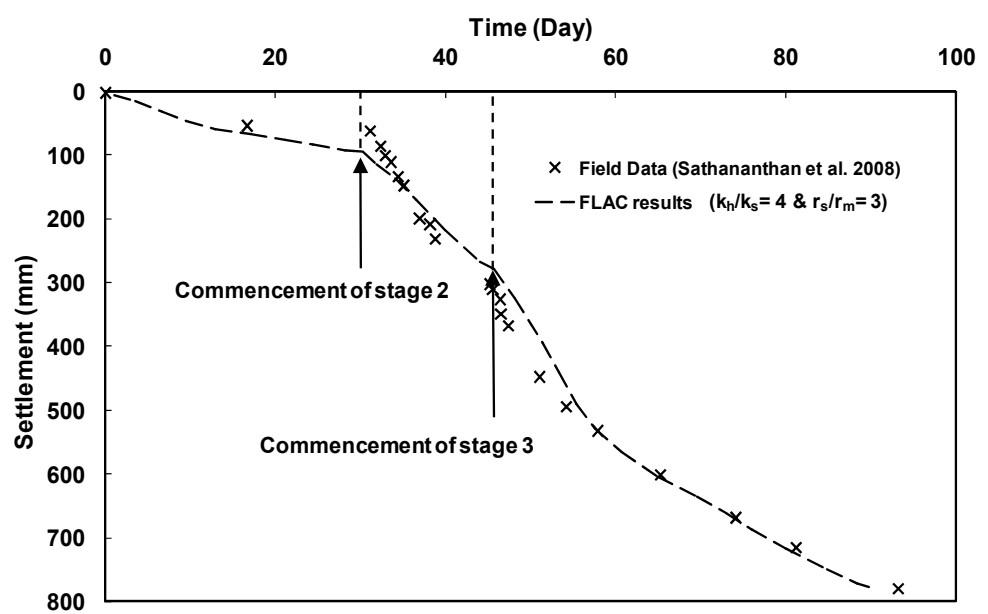

Fig. 6 Comparison of numerical results with filed data (for settlement plate P1)

Table 4 Soil properties for modified cam-clay (after Sathananthan 2005)

\begin{tabular}{cccccccccc}
\hline \hline Property & $M$ & $\lambda$ & $\kappa$ & $v$ & $e_{c s}{ }^{*}$ & $k_{h p}\left(10^{-11} \mathrm{~m} / \mathrm{s}\right)$ & $L L$ & $P I$ & $G_{s}$ \\
\hline Moruya clay & 1.1 & 0.15 & 0.05 & 0.25 & 1.55 & 9.1 & 70 & 40 & 2.63
\end{tabular}

$* e_{c s}$ is the void ratio at the critical state

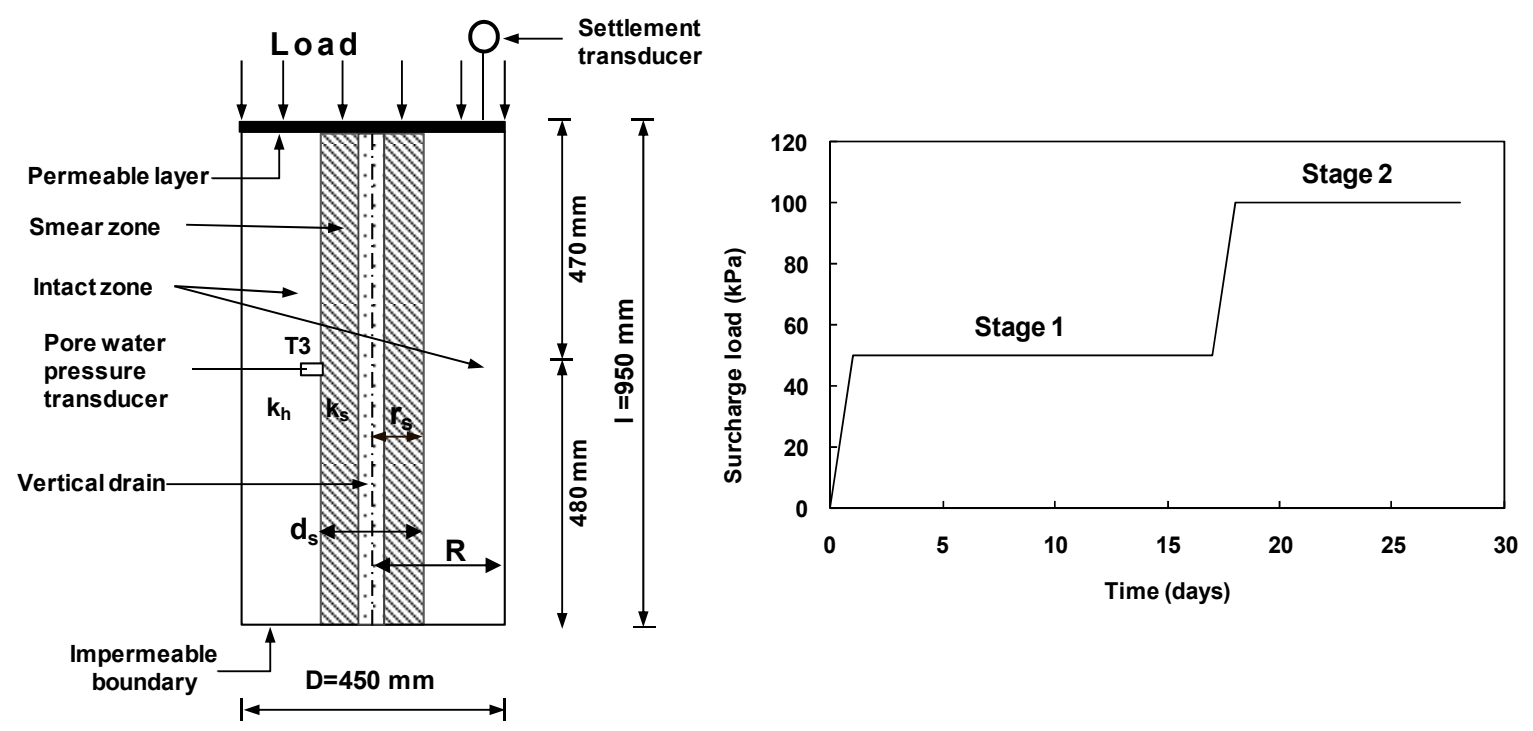

Fig. 7 Large consolidometer (modified after Indraratna and Redana 1998, and Sathananthan 2005):

(a) cross section of selected large consolidometer; (b) loading history

example, the predicted settlement at the commencement of stage 2 is $95 \mathrm{~mm}$, which is $60 \%$ greater than the field measurement of $60 \mathrm{~mm}$, whereas this difference is about $10 \%$ at the commencement of stage 3 . 


\subsection{Case study 2: Simulation of a large consolidometer}

An array of experimental data taken from a large consolidometer designed and built at the University of Wollongong, Australia by Indraratna and Redana (1998) has been used for further verification of the numerical code. The specifications of the large consolidometer with a vertical drain insertion have been explained in detail by Rujikiatkamjorn (2005). The properties of the soil adopted in this study are summarised in Table 4. Fig. 7(a) illustrates the large consolidometer schematically. The loading history adopted in this study is based on the test reported by Sathananthan (2005) as presented in Fig. 7(b).

The axisymmetric finite difference model is employed to simulate the large consolidometer. As shown in Fig. 8, zero excess pore water pressure considering hydrostatic water pressure has been adopted on the drain boundary. Uniformly distributed load is considered on top of the cell to simulate the surcharge pressure. Figs. 8(a)-(b) demonstrate the large-cell mesh grid, which is generated using the numerical code, and the pore pressure boundary condition (hydrostatic with zero excess pore water pressure) along the vertical drain, respectively.

Pore water pressure transducer T3 is selected to verify the numerical predictions with the measurements (Fig. 7(a)). The consolidation settlement and the excess pore pressure results are demonstrated in Figs. 9(a)-(b), respectively. Numerical predictions are in a good agreement with the experimental results adopting $k_{h} / k_{s}=1.5$ (permeability ratio) and $r_{s} / r_{m}=3$ (extent ratio).

As shown in Fig. 9(a), the disparities between the numerical predictions and experimental measurements increase by time, which can be associated with the viscous behaviour of the soil. The current numerical method uses constant compressibility parameters $(\lambda, \kappa)$ and ignores the viscous deformation of the soil during consolidation. According to Yin and Graham (1989) soil creep occurs during dissipation on pore water pressure contributing to larger deformations.

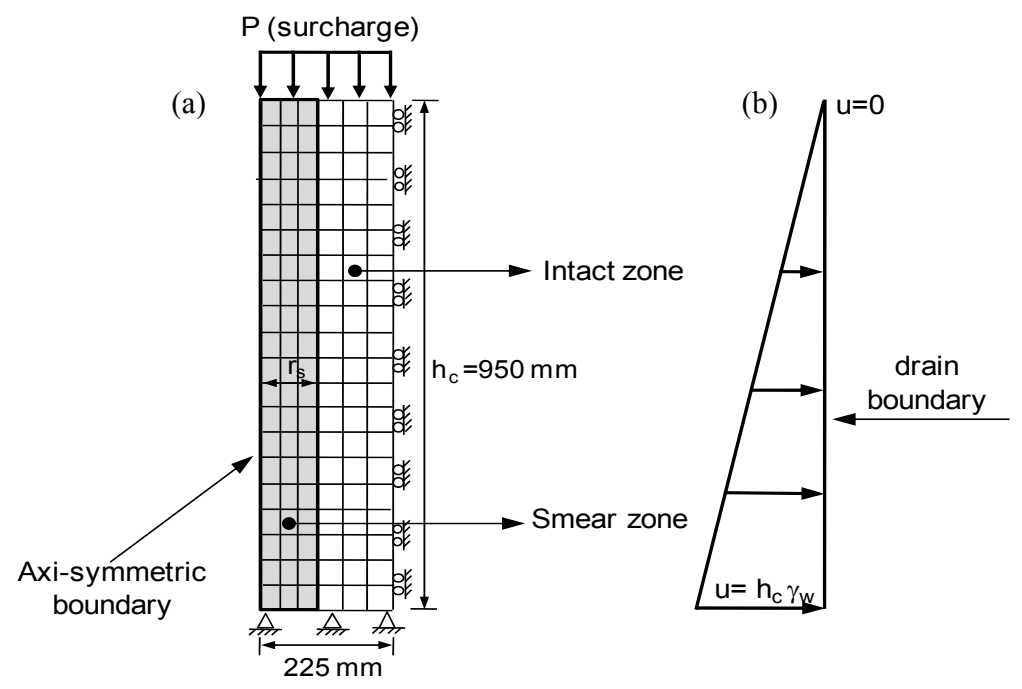

Fig. 8 Finite difference model: (a) sample of grid pattern for the large consolidometer applying developed code $\left(r_{s}=\right.$ smear zone extent; $l_{i}=$ intact zone extent; $s_{d}=$ drain space, $h_{c}=$ length of the cell, $w=$ width of the cell); (b) pore pressure distribution boundary condition along the vertical drain 


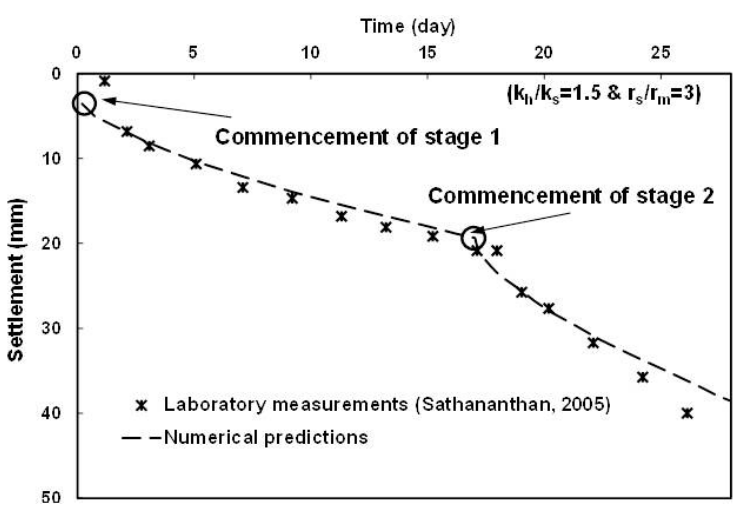

(a)

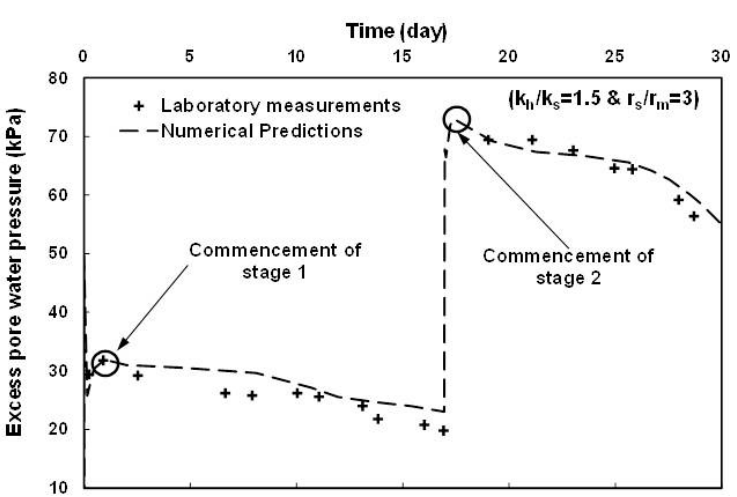

(b)

Fig. 9 Results of consolidation test using large consolidometer: (a) settlement versus consolidation time; (b) excess pore pressure versus consolidation time

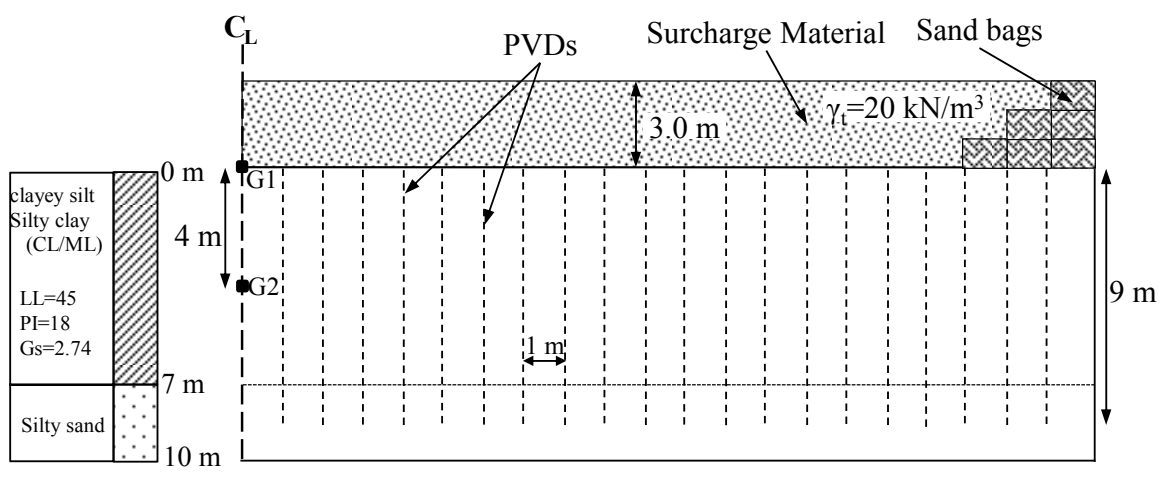

(a)

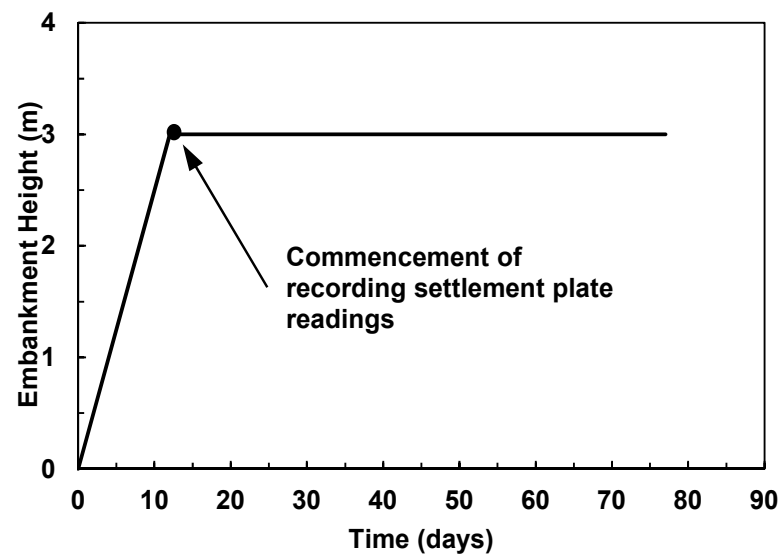

(b)

Fig. 10 Chittagong Port embankment: (a) cross section; (b) construction history 


\subsection{Case study 3: Chittagong sea port in Bangladesh}

According to Dhar et al. (2011), a container yard has been constructed at Chittagong Port, the largest sea port in Bangladesh, for handling loaded containers. The site is located on the bank of Karnafully river beside the Bay of Bengal in the Indian Ocean. The yard covers an area of 60,700 $\mathrm{m}^{2}$ and was designed to support a container load producing a contact pressure of approximately 56 $\mathrm{kPa}$. Geotechnical investigations revealed the presence of a soft to very soft clayey silt/silty clay deposit with a thickness of approximately $7 \mathrm{~m}$ (Fig. 10(a)).

Preloading with prefabricated vertical drains was adopted to preconsolidate the compressible soft deposits, which was followed by the field monitoring. Geosynthetic vertical drains were installed down to the depth of approximately $9 \mathrm{~m}$ below the ground level in square patter to cover the full depth of the soft clay. A surcharge load consisting of $3.0 \mathrm{~m}$ high fill of sand was placed for preloading. Surcharge material was placed in two layers of approximately equal thickness. The sides of the surcharge load were kept vertical along the boundaries of the area using sand bags and brick stacks. Fig. 10(a) shows a profile detailing the ground improvement work schematically. In addition, Fig. 10(b) shows the construction history of the embankment.

FLAC 2D numerical code incorporating modified Cam-Clay constitutive soil model has been employed to simulate Chittagong Port preloading process applying plane strain conditions. The zero excess pore water pressure has been considered along the vertical drains and ground surface boundary to model the PVD and surface drainage, respectively. Eq. (6) has been used to calculate the equivalent plane-strain permeability $\left(k_{h p}\right)$ required in the analysis. Adopted soil properties in the numerical analysis are summerised in Table 5.The quadrilateral elements have been used for finite difference mesh generation, which are internally subdivided into two overlaid sets of constant-strain triangular elements by FLAC (Fig. 11).

Numerical results are compared with the field measurements in Fig. 12. The average field settlement has been calculated by averaging settlement of 16 variable settlement plate results

Table 5 Adopted soil properties in FLAC simulation (after Dhar et al. 2011)

\begin{tabular}{cccccccccc}
\hline \hline Layer & Soil type & $M$ & $\lambda$ & $\kappa$ & $v$ & $e_{\circ}$ & $\gamma_{s}\left(\mathrm{kN} / \mathrm{m}^{3}\right)$ & $k_{h}\left(10^{-9} \mathrm{~m} / \mathrm{s}\right)$ & $k_{h} / k_{v}$ \\
\hline Clayey silt & Soft soil & 0.94 & 0.13 & 0.026 & 0.3 & 1.28 & 14.0 & 2.31 & 1.5 \\
\hline
\end{tabular}

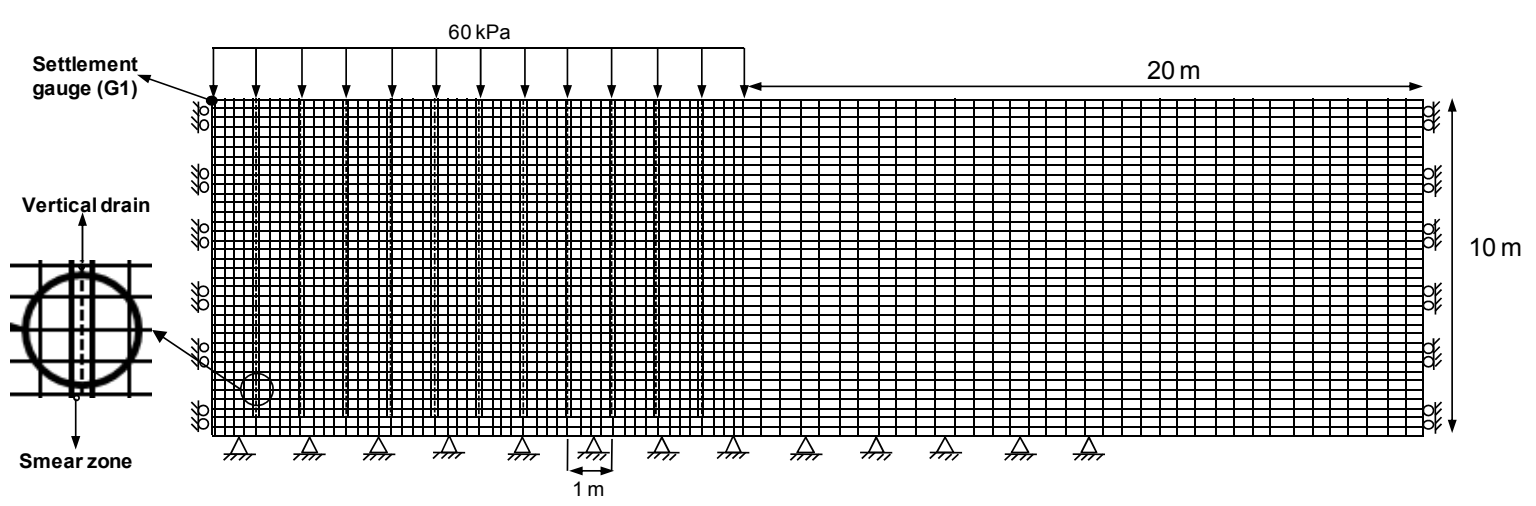

Fig. 11 Sample of mesh grid pattern for Chittagong Port embankment considering the smear 


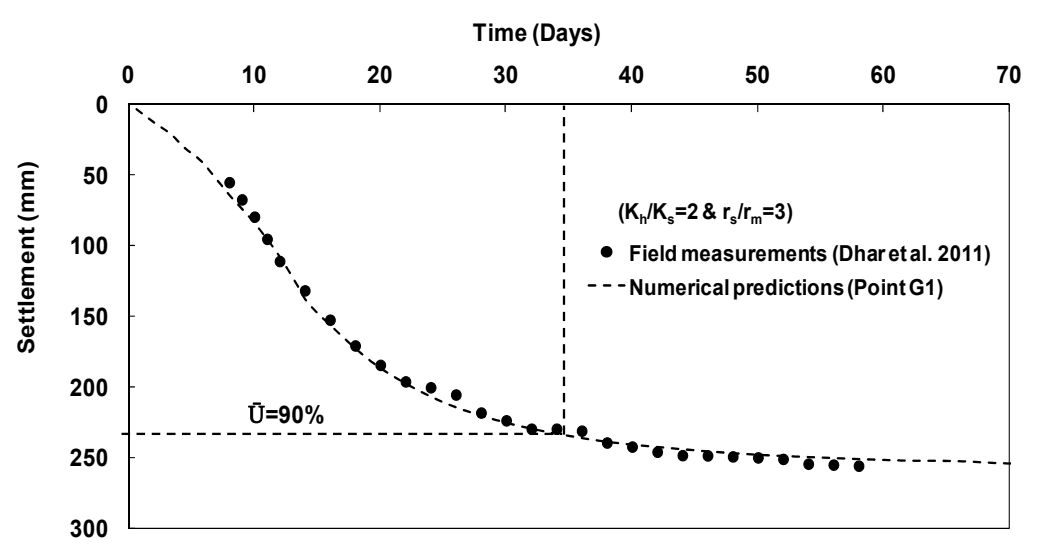

Fig. 12 Comparison of numerical results with filed data at Chittagong Port site

(SP1-10 and SP16-20) close to the centre of the embankment on the ground surface. According to Fig. 12, FLAC predictions are in a good agreement with the field measurements considering $k_{h} / k_{s}$ $=2$ and $r_{s} / r_{m}=3$. The primary consolidation settlement is predicted to be approximately $258 \mathrm{~mm}$. As illustrated in Fig. 12, the field settlement is measured immediately after placing the surcharge to the full height of $3 \mathrm{~m}$ (12 days).

\section{Parametric study}

Parametric studies have been conducted to investigate the influence of the smear zone characteristics on the preloading design simulating Chittagong Port case study with the details presented in the previous section. For this purpose, $k_{h} / k_{s}$ (permeability ratio) and $r_{s} / r_{m}$ (extent ratio) have been changed from 2 to 5. Fig. 13 illustrates the parametric study results for settlement-time relationships.

According to Fig. 13, the settlement curves are converged to a unique value of approximately $258 \mathrm{~mm}$, which is the primary consolidation settlement. The required time to obtain $90 \%$ of primary consolidation settlement $(232 \mathrm{~mm})$ has been considered to investigate the effect of smear zone properties on consolidation process. It should be noted that $90 \%$ degree of consolidation has been adopted by many researchers as an acceptable value for near completion of consolidation resulting in accurate settlement predictions (Basu et al. 2006, Saowapakpiboon et al. 2011) and also often used by practising geotechnical engineers as the indication of the time for the removal of the surcharge.

According to Fig. 13(a), a minimum duration of 33 days is required to achieve $90 \%$ degree of consolidation, considering $k_{h} / k_{s}=2$ and $r_{s} / r_{m}=2$. When smear zone properties are $k_{h} / k_{s}=5$ and $r_{s} / r_{m}=5$, the required time would be the highest and equal to 67 days, which is approximately twice longer than the minimum. According to the settlement curves in Fig. 13, the influence of smear zone permeability variations is more critical when the smear zone extent ratio is larger. For instance the required time to obtain $90 \%$ degree of consolidation has been increased by $60 \%$ (from 33 days to 53 days) changing the permeability ratio from 2 to 5 considering the extent ratio equal to 2 , while this increase is $80 \%$ (from 37 days to 67 days) for extent ratio of 5 . 


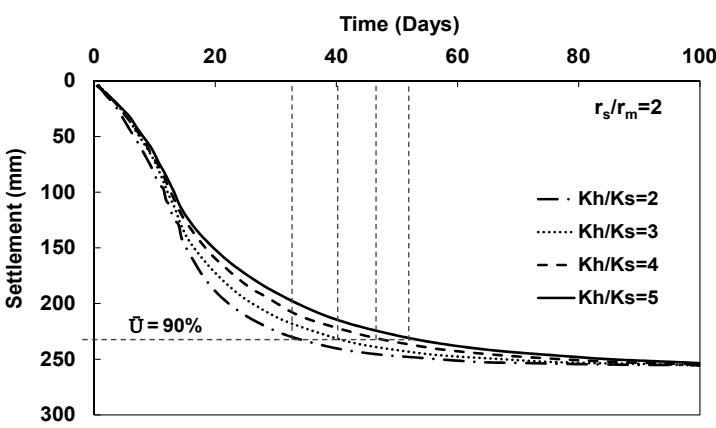

(a)

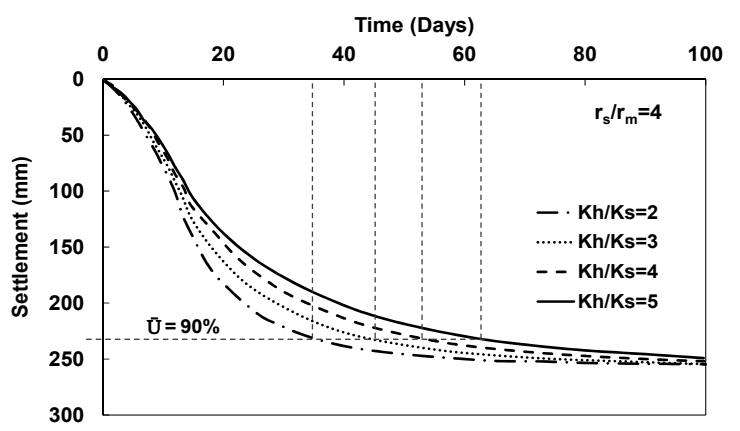

(c)

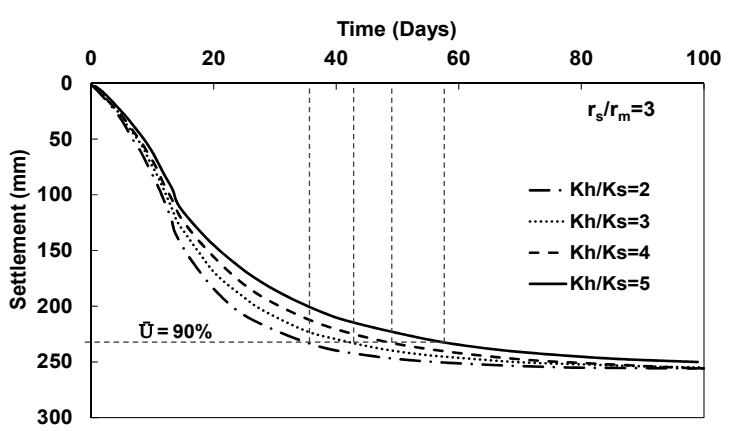

(b)

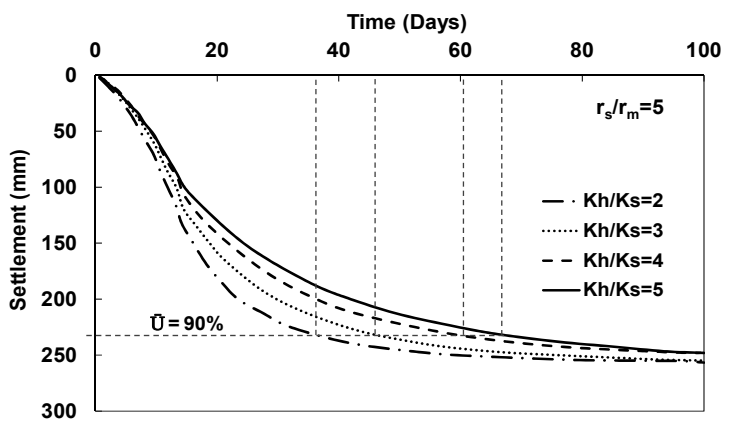

(d)

Fig. 13 Parametric study results for Chittagong Port case history at point G1

The general trend in Figs. 13(a)-(d) shows that changing the permeability ratio in a smaller range results in larger variations of the required time to obtain $90 \%$ degree of consolidation considering a constant extent ratio. According to Fig. 13(a), the consolidation time is increased by $23 \%$ by varying the permeability ratio from 2 to 3 , while this change is $17 \%$ and $12 \%$ when the permeability ratio is changed from 3 to 4 and 4 to 5 , respectively.

Fig. 14 illustrates the numerical parametric study results investigating the influence of the smear zone properties on the excess pore water pressure dissipation. Graphs are plotted for point G2 located at the depth of $4 \mathrm{~m}$ (see Fig. 9). Fig. 14 confirms that increasing the permeability and extent ratios prolongs the pore water pressure dissipation process considerably. According to Figs. 14(a)-(d), the permeability ratio is more critical parameter than the extent ratio, although the influence of extent ratio variation on the consolidation time cannot be neglected. For example, according to Fig. 14(b), there is $160 \%$ difference between the predicted excess pore pressure values after 34 days $\left(90 \%\right.$ field degree of consolidation) for $k_{h} / k_{s}=2(\mathrm{EPWP}=13 \mathrm{kPa})$ and $k_{h} / k_{s}=$ $5(\mathrm{EPWP}=34 \mathrm{kPa})$, while keeping $r_{s} / r_{m}=3$ (Fig. 14(b)).

The required time to obtain $90 \%$ degree of consolidation for different smear zone properties is illustrated in Fig. 15 using parametric study results, which presents a better interpretation of the effects of the smear zone properties on consolidation time.

According to Fig. 15, the consolidation time significantly depends on the smear zone permeability and extent. For example, assuming $r_{s} / r_{m}=2$, for the case with $k_{h} / k_{s}=2$, the required times to obtain $90 \%$ degree of consolidation are approximately 33 days and 53 days, respectively, indicating $60 \%$ difference. Difference is more significant for larger values of $r_{s} / r_{m}$. 


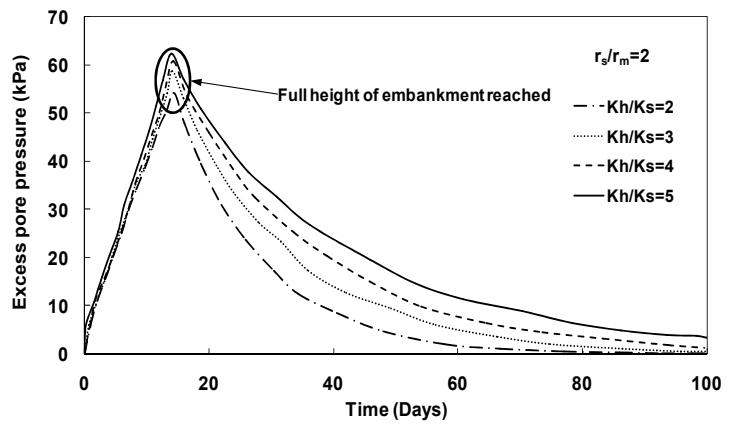

(a)

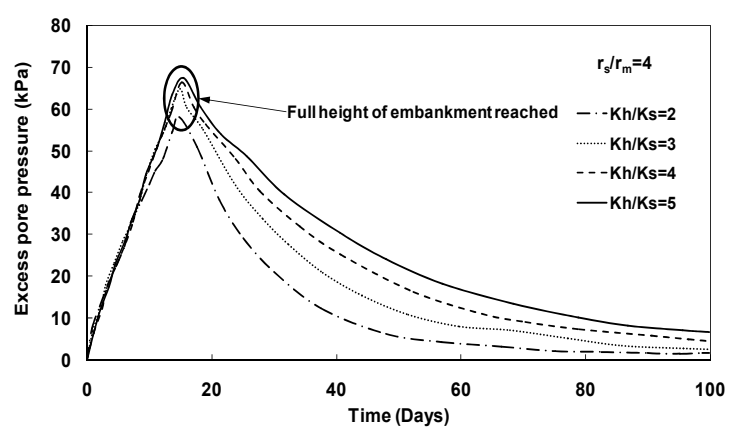

(c)

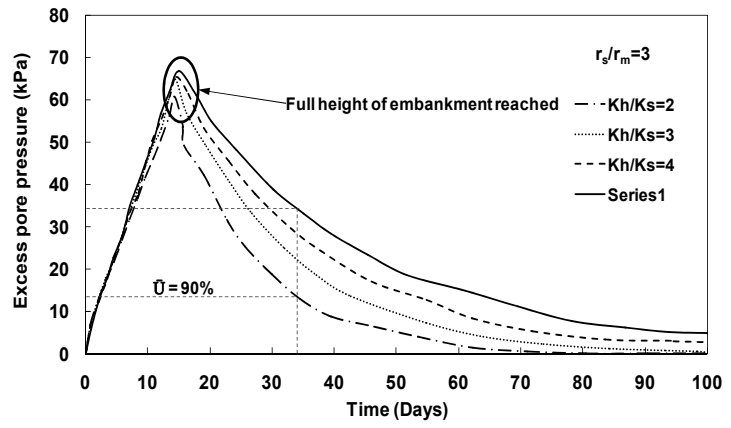

(b)

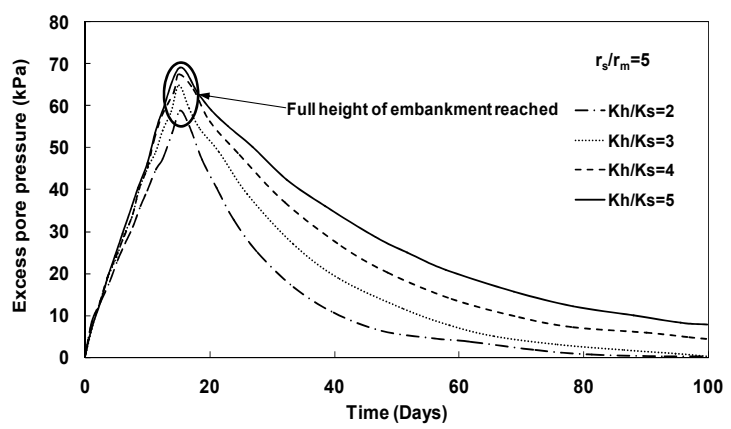

(d)

Fig. 14 Influence of smear zone properties on excess pore water pressure dissipation for Chittagong Port case history at point G2

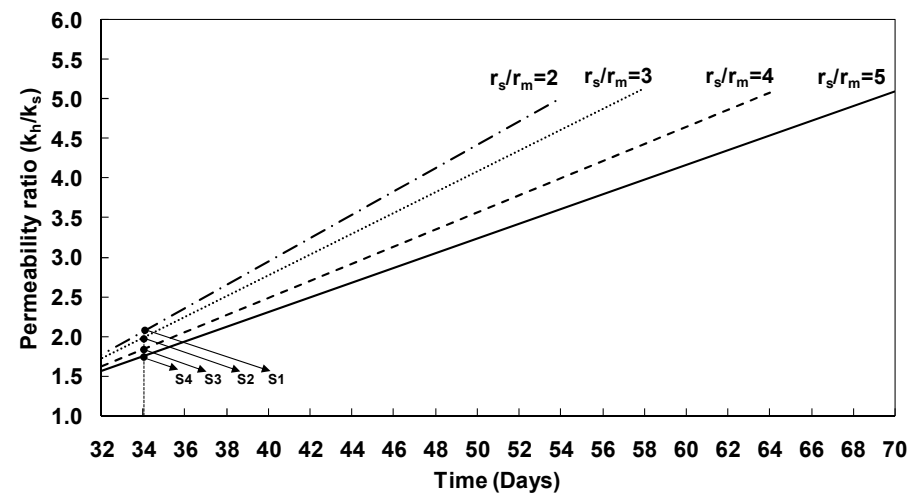

Fig. 15 Predicted time to obtain 90\% degree of consolidation

Fig. 15 clearly indicates that the smear zone extent ratio $\left(r_{s} / r_{m}\right)$ is an important parameter influencing the consolidation time and cannot be neglected. Varying $r_{s} / r_{m}$ in the range of 2 to 5, assuming $k_{h} / k_{s}$ as a constant parameter can influence the required consolidation time by more than $25 \%$. Combined effects of variability in the smear zone extent and permeability will result in momentous changes of consolidation time. Results presented in Fig. 15 clearly indicate that the 
influence of variability in $r_{s} / r_{m}$ becomes more important when permeability of smear zone decreases.

According to the back-calculation results presented in Fig. 12, the predicted settlement curve isin the best agreement with the field measurements considering smear zone properties of $k_{h} / k_{s}=2$ and $r_{s} / r_{m}=3$. The required time to obtain $90 \%$ degree of consolidation for this condition is equal to 34 days, which is highlighted as point S2 in Fig. 15. A vertical line is plotted from $t_{90 \%}=34$ days, which intersects the set of lines at points S1, S2, S3 and S4. Smear zone properties at these points are summarised in Table 6.

Numerical analyses applying developed FLAC code have been conducted to compare the settlement and excess pore water pressure variations against the consolidation time. Different combinations of smear zone extent and permeability resulting in the same $t_{90 \%}=34$ days and results are presented in Fig. 16.

Fig. 16 shows that the curves for the settlement variations and the excess pore water pressure dissipations with time follow the same trend for points S1, S2, S3 and S4. Therefore, smear zone properties of any of these points can be adopted for practical design purposes to reduce inaccuracies. In other words, the extent ratio $\left(r_{s} / r_{m}\right)$ can be assumed to be a constant value and the permeability ratio $\left(k_{h} / k_{s}\right)$ can be changed to conduct the parametric study and determine the optimum combination. A back-calculation procedure (as shown in Fig. 17) has been designed and integrated in the numerical code to define the smear zone properties, resulting in the best fit to the field measurements.

As is illustrated in flowchart of Fig. 17, the approach starts with collecting the input data including soil properties, PVD assisted preloading specifications, and field monitoring results. The first stage is completed by defining the initial values, the minimum and maximum ratios, and the incremental rates for both extent and permeability ratios. In the second stage, a systematic

Table 6 Back-calculated smear zone properties to achieve $\mathrm{t}_{90 \%}=34$ days

\begin{tabular}{ccccc}
\hline \hline Point & $\mathrm{S} 1$ & $\mathrm{~S} 2$ & $\mathrm{~S} 3$ & $\mathrm{~S} 4$ \\
\hline$k_{h} / k_{s}$ & 2.10 & 2.0 & 1.85 & 1.75 \\
$r_{s} / r_{m}$ & 2 & 3 & 4 & 5 \\
\hline
\end{tabular}

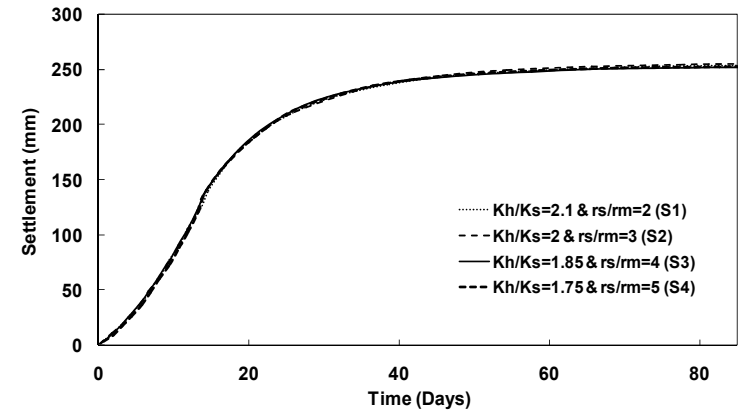

(a)

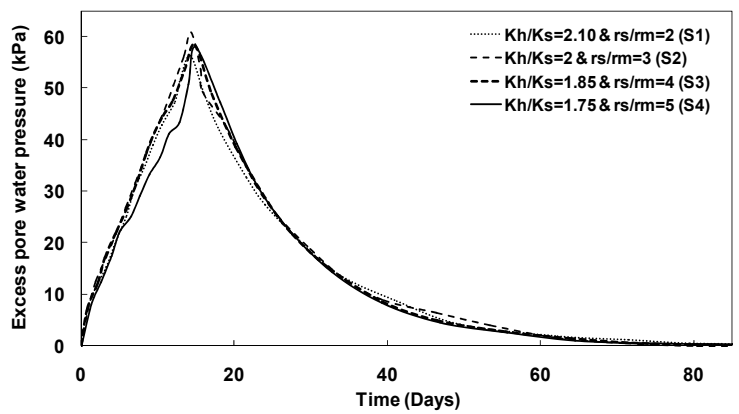

(b)

Fig. 16 Results of FLAC analysis for points in Table 7 using the Chittagong Port case history: (a) settlement variation; (b) dissipation of excess pore water pressure 


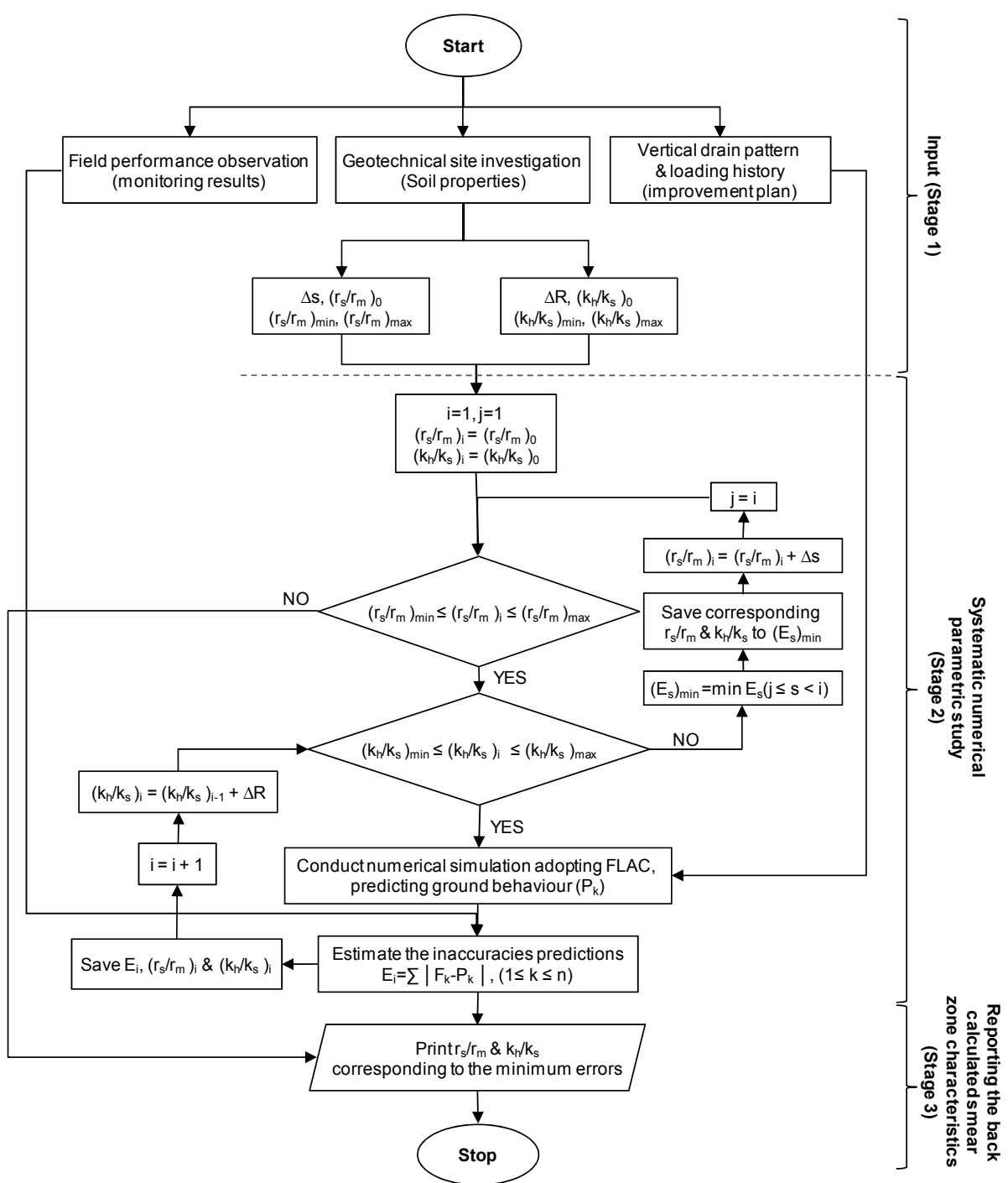

\begin{tabular}{|c|l|c|l|}
\hline$\left(r_{s} / r_{m}\right)_{0}$ & assumed initial extent ratio & $\Delta R$ & $\begin{array}{l}\text { permeability ratio increment depending on the } \\
\text { required accuracy }\end{array}$ \\
\hline$\left(k_{h} / k_{s}\right)_{0}$ & assumed initial permeability ratio & $\Delta S$ & extent ratio increment depending on the required accuracy \\
\hline$\left(r_{s} / r_{m}\right)_{\min }$ & minimum extent ratio & $E_{i}$ & $\begin{array}{l}\text { error between numerical predictions and field measurements } \\
\text { at step } i\end{array}$ \\
\hline$\left(r_{s} / r_{m}\right)_{\max }$ & maximum extent ratio & $\left(E_{\min }\right)_{s}$ & minimum error corresponding to step $s$ \\
\hline$\left(k_{h} / k_{s}\right)_{\min }$ & minimum permeability ratio & $\left(r_{s} / r_{m}\right)_{s}$ & $\begin{array}{l}\text { extent ratio corresponding to step } s \text { that gives the minimum } \\
\text { error }\end{array}$ \\
\hline$\left(k_{h} / k_{s}\right)_{\max }$ & maximum permeability ratio & $\left(k_{h} / k_{s}\right)_{s}$ & $\begin{array}{l}\text { permeability ratio corresponding to step } s \text { that gives the } \\
\text { minimum error }\end{array}$ \\
\hline$\left(r_{s} / r_{m}\right)_{i}$ & extent ratio at step $i$ & $F_{k}$ & Field measurements \\
\hline$\left(k_{h} / k_{s}\right)_{i}$ & permeability ratio at step $i$ & $P_{k}$ & Numerical predictions \\
\hline
\end{tabular}

Fig. 17 Back-calculation flowchart 
parametric study has been designed by varying the extent and the permeability ratios to back-calculate and save different combinations of smear zone properties resulting in minimum errors at every loop of calculations. Stage two stops as soon as the extent ratio is out of the input range. The last stage of the illustrated flowchart in Fig. 17 is to report the back-calculated pairs of smear zone extent and permeability corresponding to the minimum errors. It should be mentioned that in Stages 2 and 3, the FLAC output has been linked to a visual basic code to calculate the error and report the results.

\section{Minimum required degree of consolidation}

One of the most reliable methods to estimate accurate smear zone properties is to construct a trial embankment and back-calculate the required design parameters (Kelly 2008). Furthermore, the construction of a trial embankment can be used to investigate the consolidation behaviour of the soft soil and evaluate the feasibility of preloading with vertical drains. The major challenge in this approach is the long waiting time to obtain $90 \%$ degree of consolidation after construction of the trial embankment and may cause a considerable delay in the construction of the actual embankment and a significant increase in the project cost. Accurate estimation of the smear zone permeability and extent in the early stages of the trial embankment construction can convert this method to a practical, accurate and cost effective method. In this study, a four-step solution is proposed to determine the minimum degree of consolidation (minimum preloading time) for the explained case studies resulting in well-predicted smear zone properties.

\subsection{Step I: Estimation of primary consolidation settlement}

The final settlement for each case study under the embankment surcharge has been predicted applying the developed numerical code. The complete dissipation of excess pore water pressure has been considered as the criteria to determine the primary consolidation settlement. The final settlement can be used to determine the degree of consolidation at any time during or after construction of the trial embankment using Eq. (10).

$$
U \%=\frac{S_{t}}{S_{f}} \times 100
$$

where $U \%$ is the degree of consolidation at time $t, s_{t}$ is the field settlement at time $t$, and $s_{f}$ is the predicted final primary consolidation settlement. Table 7 shows the primary consolidation settlement and the corresponding degree of consolidation for the simulated case studies.

It should be noted that in this study as a simplifying assumption, the effects of soil creep during the excess pore water pressure dissipation have been ignored. It should be considered that the key purpose of this study is establishing the minimum required degree of consolidation to back-calculate smear zone properties reliably. Thus, it is more practical to adopt conventional consolidation theory to predict the settlement at the end of primary consolidation. However as reported by Yin and Graham (1989), Le et al. (2012) and Fatahi et al. (2013), adopting elastoviscoplastic soil model, the soil creep due to the drainage of pore fluid in micropores, or due to the structural viscosity of pore fluids, can be simulated explicitly during the excess pore water pressure dissipation. 
Table 7 Primary consolidation settlement and the corresponding degree of consolidation

\begin{tabular}{|c|c|c|c|}
\hline Case study & $\begin{array}{l}\text { Sunshine } \\
\text { at P1 }\end{array}$ & $\begin{array}{c}\text { Large } \\
\text { consolidometer test }\end{array}$ & $\begin{array}{c}\text { Chittagong } \\
\text { sea port }\end{array}$ \\
\hline Primary settlement (m) & 1.75 & 0.086 & 0.258 \\
\hline Field settlement at the end of preloading (m) & 0.75 & 0.045 & 0.258 \\
\hline Preloading time (day) & 90 & 30 & 55 \\
\hline Degree of consolidation at the end of preloading $(\%)$ & $40 \%$ & $52 \%$ & $100 \%$ \\
\hline
\end{tabular}

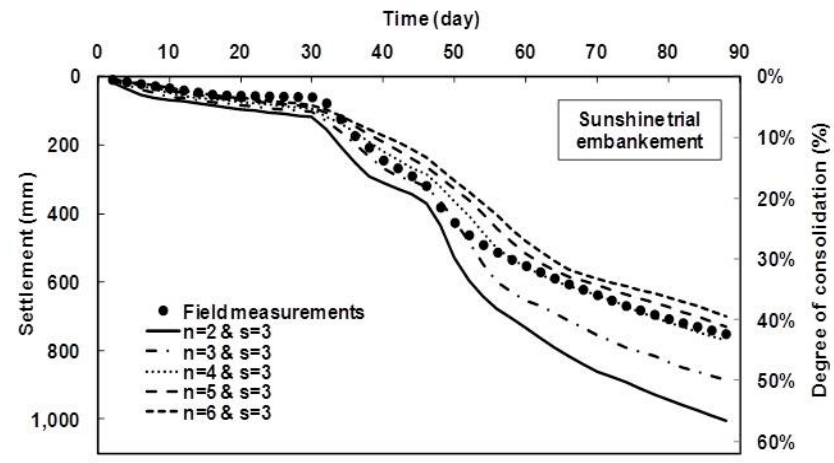

(a)

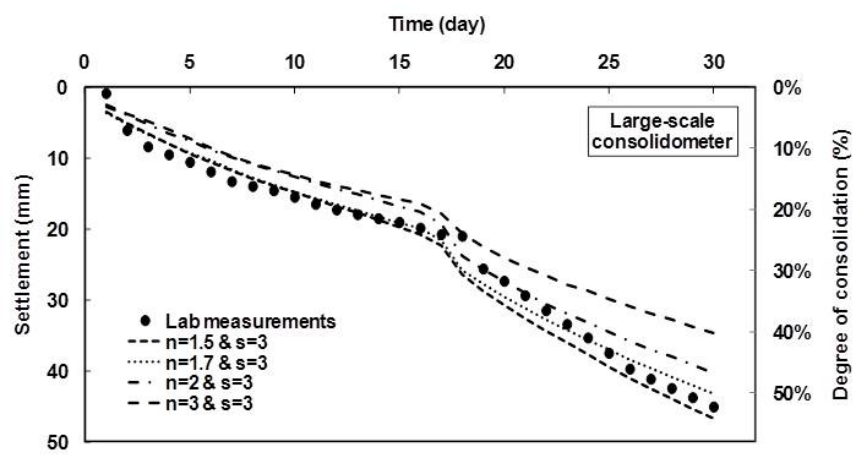

(b)

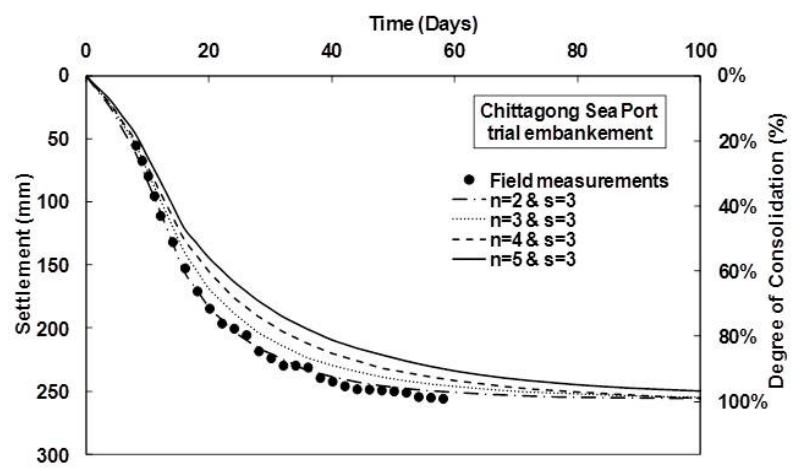

(c)

Fig. 18 Results of the numerical parametric study (Settlement versus consolidation time) 


\subsection{Stage III: Error determination}

According to Figs. 18(a)-(c), the observational technique cannot be employed to predict precise smear zone properties in the very early stages of the trial embankment construction resulting in the settlement curves having the best agreement with the measurements. Therefore, it is required to determine the existing error between the field measurements and numerical predictions for the applied smear zone properties at every degree of consolidation and find the optimum combination of $r_{s} / r_{w}$ and $k_{h} / k_{s}$. For this purpose, the normalised accumulative error at each stage of the consolidation process is calculated using Eq. (11).

$$
\left(E_{t}\right)_{n}=\sum_{i=1}^{n} \frac{\left(S_{t}\right)_{i-}\left(S_{t p}\right)_{i}}{N \times S_{f}}
$$

where, $E_{t}$ is the normalised accumulative error at time $t, n$ is the observation point number, $N$ is the total number of observation points, $S_{t}$ is the field settlement at time $t, S_{t p}$ is the predicted settlement at time $t$, and $S_{f}$ is the final primary consolidation settlement.

The curves in Fig. 19 show the changes of normalised accumulative error with the degree of consolidation for three case studies adopting the selected combinations of smear zone properties.

In each case study, the best predicted smear zone properties $\left(s=r_{s z} / r_{w}\right.$ and $\left.n=k_{h} / k_{s}\right)$, belong to the case with the minimum final accumulative error. The final accumulative errors for different combinations of $n$ and $s$ are shown in Table 8. The highlighted cells are the smear zone properties resulting in the minimum final accumulative error and the corresponding curve has the best fit with the field measurements, which can be reported as the best predicted smear zone characteristics.

\subsection{Step IV: Determination of minimum required waiting time}

Figs. 19(a)-(c) indicate that the estimation of the smear zone characteristics at the very early

Table 8 Final accumulative errors for different combinations smear zone properties

\begin{tabular}{ccccc}
\hline \hline \multicolumn{5}{c}{ Sunshine trial embankment } \\
\hline$n\left(k_{h} / k_{s}\right)$ & 2 & 3 & 4 & 5 \\
$s\left(r_{s} / r_{m}\right)$ & 3 & 3 & 3 & 3 \\
$E_{f}^{*}$ & 0.068 & 0.034 & 0.010 & 0.018 \\
\hline \multicolumn{5}{c}{ Large consolidometer test } \\
\hline$n\left(k_{h} / k_{s}\right)$ & 1.5 & 1.7 & 2 & 3 \\
$s\left(r_{s} / r_{m}\right)$ & 3 & 3 & 3 & 3 \\
$E_{f}$ & 0.2 & 0.15 & 0.3 & 0.53 \\
\hline \multicolumn{5}{c}{ Chittagong sea port trial embankment } \\
\hline$n\left(k_{h} / k_{s}\right)$ & 2 & 3 & 4 & 5 \\
$s\left(r_{s} / r_{m}\right)$ & 3 & 3 & 3 & 3 \\
$E_{f}$ & 0.22 & 0.34 & 0.67 & 1.03 \\
\hline
\end{tabular}

$* E_{f}$ is the final accumulative error 


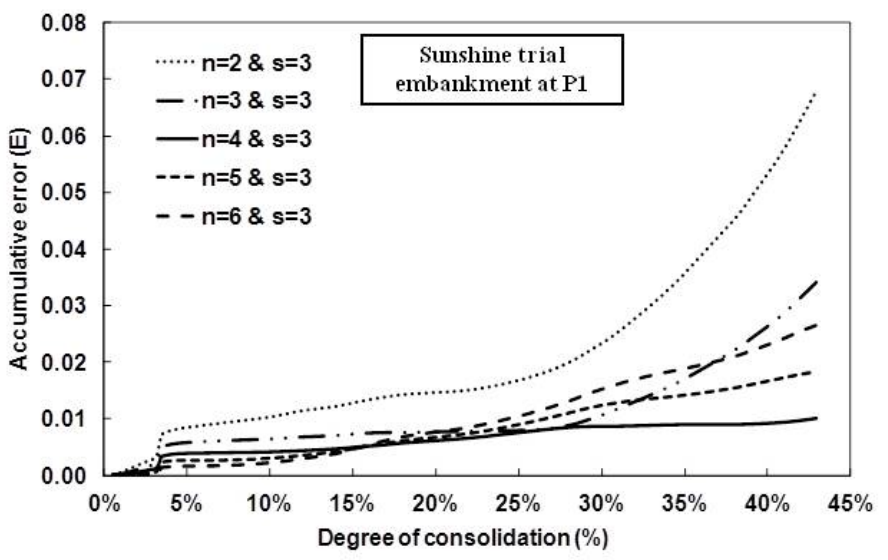

(a)

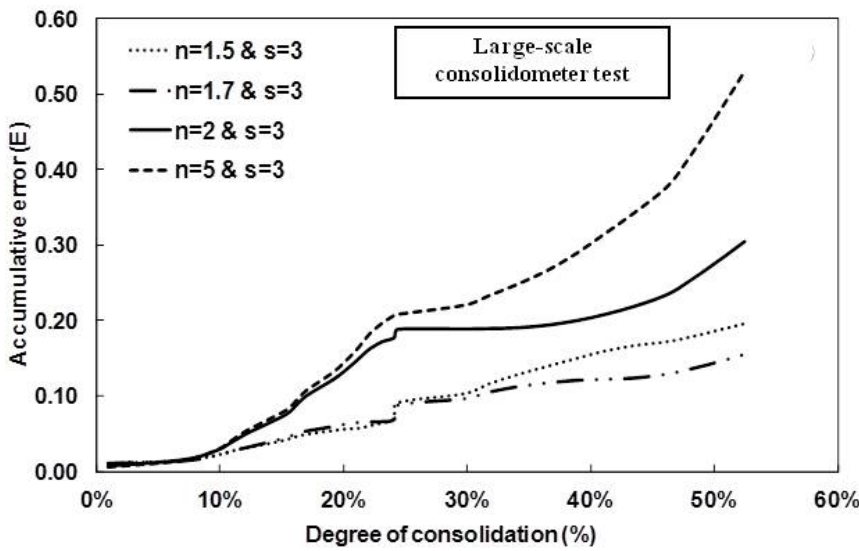

(b)

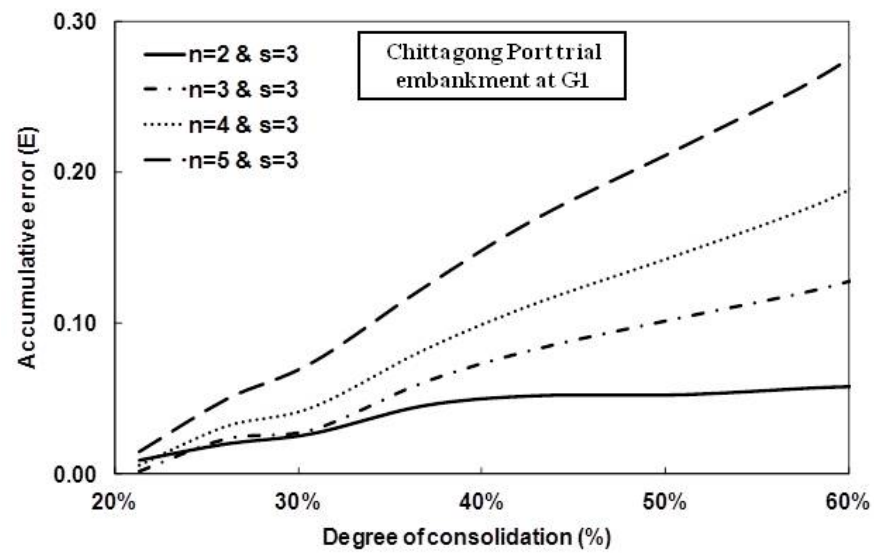

(c)

Fig. 19 Normalised accumulative error versus degree of consolidation for different smear zone properties 
stages after applying the surcharge is a challenging task and accurate values may not be obtained. To determine the minimum required degree of consolidation (minimum waiting time after applying the surcharge) resulting in the back-calculation of the most accurate $r_{s} / r_{w}$ and $k_{h} / k_{s}$ values,

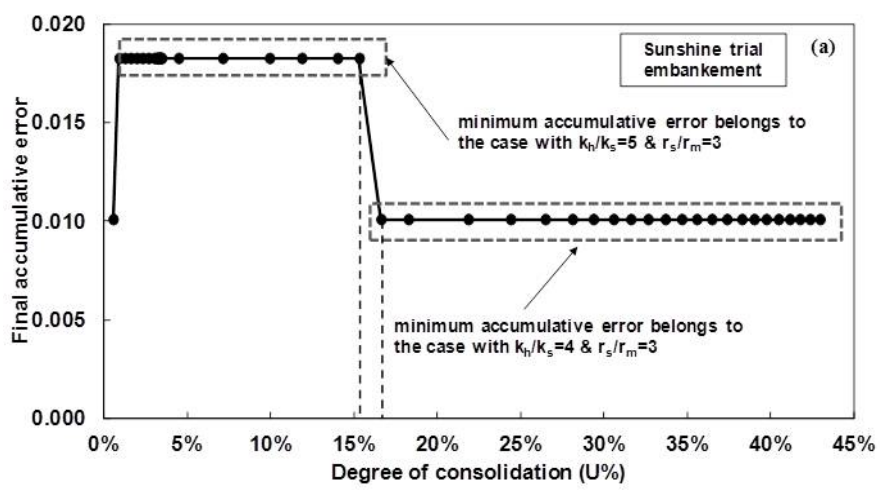

(a)

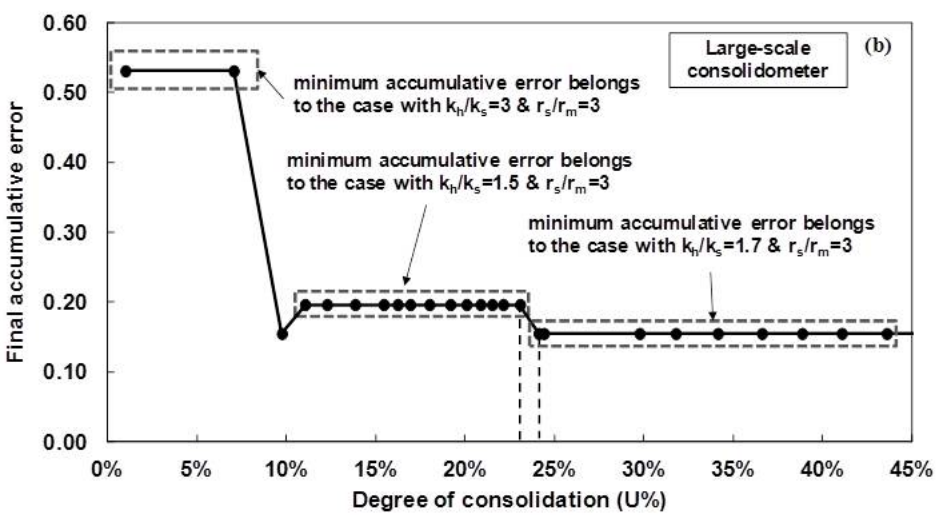

(b)

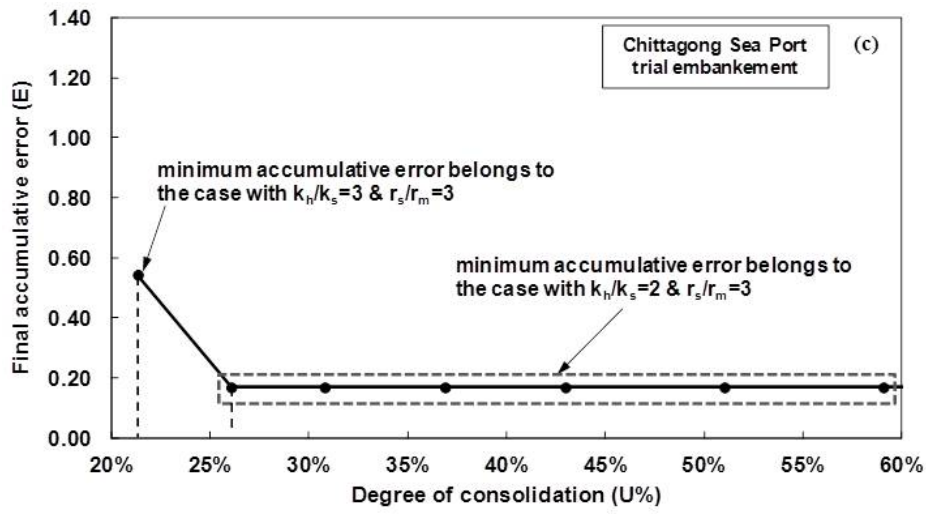

(c)

Fig. 20 Total accumulative error (for the smear zone properties resulting in minimum accumulative error) versus degree of consolidation 
the final accumulative error corresponding to the case with the minimum accumulative error at every degree of consolidation is determined and the results are plotted in Figs. 20(a)-(c).

The minimum required degree of consolidation and corresponding time belong to the first point with the minimum final accumulative error. The predicted smear zone properties $\left(r_{s} / r_{m}\right.$ and $\left.k_{h} / k_{s}\right)$ at that point can be reported as the reliable values for the practical design purposes.

According to the plotted graph in Fig. 20(a), the final accumulative error for the Sunshine trial embankment has a constant and minimum value of 0.01 after $16 \%$ degree of consolidation, which belongs to the case with $k_{h} / k_{s}=4$ and $r_{s} / r_{m}=3$. Therefore, $16 \%$ can be reported as the minimum required degree of consolidation to estimate accurate smear zone permeability and extent. Fig. 20(b) shows that for the large consolidometer test, there is no change in the value of final accumulative error after $24 \%$ degree of consolidation, corresponding to the case with the smear zone properties of $r_{s} / r_{w}=1.7$ and $k_{h} / k_{s}=3$. Therefore, the most accurate smear zone properties can be back-calculated when $24 \%$ degree of consolidation is obtained. Fig. 20(c) illustrates the minimum final accumulative error of 0.17 after obtaining $25 \%$ degree of consolidation for the Chittagong trial embankment, which belongs to the case with the smear zone properties of $r_{s} / r_{w}=2$ and $k_{h} / k_{s}=3$. The Chittagong trial embankment results confirm that the smear zone permeability and extent can be estimated accurately at the early stages of the consolidation.

According to the conducted analyses and the obtained results from the simulated case studies, the construction of trial embankment with field measurements is recommended as a practical solution to estimate the smear zone properties as accurate as possible, and the minimum required waiting time should be designed to obtain at least 30\% degree of consolidation. It should be noted that authors have already conducted several other case studies which were not reported in this paper because of page limitations. The currently reported case studies as well as the other case studies (6 case studies) conducted by the authors, confirm that when at least $30 \%$ degree of consolidation is achieved, the smear zone properties can be back-calculated reliably using the numerical procedure presented in this study.

\section{Conclusions}

Preloading time during consolidation process can significantly be affected by formation of the smear zone in the vicinity of the prefabricated vertical drains (PVDs). Available literature, proposes a wide range for the smear zone extent and permeability and yet there is no definite prediction method that can be used to estimate the extent of smear zone and its permeability to be used in the design. In this study, analytical solutions and numerical analyses have been employed to investigate the effects of variability of PVD smear zone characteristics on the preloading design. Analytical parametric study for a simplified case confirms that the smear zone permeability and extent have great effects on the consolidation time. Results show that the influence of variability in the extent ratio $\left(r_{s} / r_{m}\right)$ is more significant while permeability ratio is larger. FLAC 2D software has been employed to develop a numerical code assisting with the parametric study and back-calculating the smear zone properties. The verification performed on three case studies confirms the validity of the developed numerical code. According to the parametric study results the properties of the smear zone play a key role on the time required to achieve a specific degree of consolidation equivalent to soil strength and stiffness which will satisfy both bearing capacity and settlement design criteria. Therefore, accurate estimation of the properties of smear zone based on the soil type and the installation method is vital for ground improvement projects adopting PVD 
assisted preloading. Results of this study indicate that assumptive properties for smear zone characteristics may result in inaccurate predictions of ground deformations and pore water pressures. This can lead to early removal of surcharge in construction process resulting in excessive post construction settlement. Thus, it is recommended to practising geotechnical engineers to back-calculate the smear zone properties using a trial construction similar to the future construction procedure or early stages of actual project embankment. A back-calculation procedure similar to the flowchart shown in Fig. 17 in conjunction with the developed FLAC numerical code can be used for a systematic base-calculation procedure to define the smear zone properties. It is observed that through the developed back-calculation approach several pairs of interrelated smear zone extent and permeability values can be obtained resulting in reliable results. A back analysis based procedure has been proposed to determine the minimum required degree of consolidation and the corresponding waiting time after construction of the trial embankment resulting in accurate back-calculated smear zone properties. The results of this study indicate that the properties of the smear zone can be well back-calculated after reaching at least an average degree of consolidation of $30 \%$.

\section{Acknowledgments}

The authors gratefully acknowledge the financial assistance from the Australian Research Council (LP0991643). The contributions and feedback from Menard Bachy Pty Ltd., particularly Mr. Daniel Berthier are very much appreciated.

\section{References}

Abuel-Naga, H.M., Bergado, D.T. and Chaiprakaikeow, S. (2006), "Innovative thermal technique for enhancing the performance of prefabricated vertical drain during the preloading process", Geotext. Geomembr., 24(6), 359-370.

Artidteang, S., Bergado, D.T., Saowapakpiboon, J., Teerachaikulpanich, N. and Kumar, A. (2011), "Enhancement of efficiency of prefabricated vertical drains using surcharge, vacuum and heat preloading", Geosynth. Int., 18(1), 35-47.

Arulrajah, A., Nikraz, H. and Bo, M.W. (2005), "Finite element modelling of marine clay deformation under reclamation fills", Ground Improvement, 9(3), 105-118.

Asaoka, A. (1978), "Observational procedure of settlement prediction”, Soil Found., 18(4), 87-101.

Barron, R.A. (1948), "Consolidation of fine-grained soils by drain wells”, T. Am. Soc. Civil Eng., 113(1), 718-742.

Basu, D. and Prezzi, M. (2009), "Design of prefabricated vertical drains considering soil disturbance", Geosynth. Int., 16(3), 147-157.

Basu, D., Basu, P. and Prezzi, M. (2006), "Analytical solutions for consolidation aided by vertical drains", Geomech. Geoeng., 1(1), 63-71.

Chai, J. and Miura, N. (1999), "Investigation of factors affecting vertical drain behavior", J. Geotech. Geoenviron. Eng., 125(3), 216-226.

Chai, J., Carter, J.P. and Hayashi, S. (2006), "Vacuum consolidation and its combination with embankment loading”, Can. Geotech. J., 43(10), 985-996.

Chai, J.C., Hong, Z.-S. and Shen, S.-L. (2010), "Vacuum-drain method induced pressure distribution and ground deformation", Geotext. Geomembr., 28(6), 525-535.

Choo, Y., Kim, J., Park, H. and Kim, D. (2013), "Development of a new asymmetric anchor plate for prefabricated vertical drain installation via centrifuge model tests", J. Geotech. Geoenviron. Eng., 139(6), 
987-992.

Dhar, A.S., Siddique, A. and Ameen, S.F. (2011), "Ground improvement using pre-loading with prefabricated vertical drains", Int. J. Geoeng. Case Histories, 2(2), 86-104.

Eriksson, U., Hansbo, S. and Torstensson, B.A. (2000), "Soil improvement at Stockholm-Arlanda airport", Ground Improvement, 4(2), 73-80.

Fatahi, B., Khabbaz, H. and Indraratna, B. (2009), "Parametric studies on bioengineering effects of tree root-based suction on ground behaviour", Ecol. Eng., 35(10), 1415-1426.

Fatahi, B., Basack, S., Premananda, S. and Khabbaz, H. (2012), "Settlement prediction and back analysis of Young's modulus and dilation angle of stone columns", Australian J. Civil Eng., 10(1), 67-78.

Fatahi, B., Le, T., Le, M. and Khabbaz, H. (2013), "Soil creep effects on ground lateral deformation and pore water pressure under embankments", Geomech. Geoeng.: Int. J., 8(2), 107-124.

Ghandeharioon, A., Indraratna, B. and Rujikiatkamjorn, C. (2010), "Analysis of soil disturbance associated with mandrel-driven prefabricated vertical drains using an elliptical cavity expansion theory", Int. J. Geomech., 10(2), 53-64.

Hansbo, S. (1981), "Consolidation of fine-grained soils by prefabricated drains", Proceedings of the 10th International Conference on Soil Mechanics and Foundation Engineering, Stockholm, Sweden, Balkema, Rotterdam, the Netherlands, June, pp. 677-682.

Hawlader, B.C. and Muhunthan, B. (2002), "Numerical study of the factors affecting the consolidation of clay with vertical drains", Geotext. Geomembr., 20(4), 213-239.

Hokmabadi, A.S., Fatahi, B. and Samali, B. (2014a), “Assessment of soil-pile-structure interaction influencing seismic response of mid-rise buildings sitting on floating pile foundations", Comput. Geotech., 55(1), 172-186.

Hokmabadi, A.S., Fatahi, B. and Samali, B. (2014b), "Seismic response of mid-rise buildings on shallow and end-bearing pile foundations in soft soil", Soil. Found., 54(3), 345-363.

Indraratna, B. and Redana, I.W. (1997), "Plane-strain modeling of smear effects associated with vertical drains", J. Geotech. Geoenviron. Eng., 123(5), 474-478.

Indraratna, B. and Redana, I.W. (1998), "Laboratory determination of smear zone due to vertical drain installation”,J. Geotech. Geoenviron. Eng., 124(2), 180-184.

Indraratna, B. and Redana, I.W. (2000), "Numerical modeling of vertical drains with smear and well resistance installed in soft clay", Can. Geotech. J., 37(1), 132-145.

Indraratna, B., Rujikiatkamjorn, C. and Sathananthan, I. (2005a), "Analytical and numerical solutions for a single vertical drain including the effects of vacuum preloading”, Can. Geotech. J., 42(4), 994-1014.

Indraratna, B., Sathananthan, I., Rujikiatkamjorn, C. and Balasubramaniam, A.S. (2005b), “Analytical and numerical modeling of soft soil stabilised by prefabricated vertical drains incorporating vacuum preloading”, Int. J. Geomech., 5(2), 114-124.

Indraratna, B., Aljorany, A. and Rujikiatkamjorn, C. (2008), "Analytical and numerical modeling of consolidation by vertical drain beneath a circular embankment”, Int. J. Geomech., 8(3), 199-206.

Indraratna, B., Rujikiatkamjorn, C., Balasubramaniam, A.S. and McIntosh, G. (2012), "Soft ground improvement via vertical drains and vacuum assisted preloading", Geotext. Geomembr., 30, 16-23.

Kelly, R.B. (2008), "Back analysis of the cumbalum trial embankment", Australian Geomech. J., 43(1), 47-54.

Le, T.M., Fatahi, B. and Khabbaz, H. (2012), "Viscous behaviour of soft clay and inducing factors", Geotech. Geol. Eng., 30(5), 1069-1083.

Lee, N.K. and Chung, S.G. (2010), "Reevaluation of the factors influencing the consolidation of ground by incorporating prefabricated vertical drains", KSCE J. Civil Eng., 14(2), 155-164.

Lo, D.O.K. (1991), "Soil improvement by vertical drains", Ph.D. Thesis, University of Illinois at UrbanaChampaign, Champaign, IL, USA.

Madhav, M.R., Park, Y.M. and Miura, N. (1993), "Modelling and study of smear zones around band shaped drains", Soil. Found., 33(4), 135-147.

Marti, J. and Cundall, P. (1982), "Mixed discretization procedure for accurate modelling of plastic collapse", Int. J. Numer. Anal. Method. Geomech, 6(1), 129-139. 
Onoue, A. (1988), "Consolidation by vertical drains taking well resistance and smear into consideration", Soil. Found., 28(4), 165-174.

Queensland Department of Transport, Sunshine Motorway Stage 2 (1992), "Performance of the Trial Embankment Area 2A (Ch 28490-28640)", Report R1802, Materials and Geotechnical Services Branch.

Rowe, R.K. and Taechakumthorn, C. (2008), "Combined effect of PVDs and reinforcementon embankments over rate-sensitive soils", Geotext. Geomembr., 26(3), 239-249.

Rujikiatkamjorn, C. (2005), "Analytical and numerical modelling of soft clay foundation improvement via prefabricated vertical drains and vacuum preloading", Ph.D. Thesis, University of Wollongong, Wollongong, Australia.

Rujikiatkamjorn, C. and Indraratna, B. (2009), "Design procedure for vertical drains considering a linear variation of lateral permeability within the smear zone", Can. Geotech. J., 46(3), 270-280.

Saowapakpiboon, J., Bergado, D.T., Youwai, S., Chai, J.C., Wanthong, P. and Voottipruex, P. (2010), "Measured and predicted performance of prefabricated vertical drains (PVDs) with and without vacuum preloading", Geotext. Geomembr., 28(1), 1-11.

Saowapakpiboon, J., Bergado, D.T., Voottipruex, P., Lam, L.G. and Nakakuma, K. (2011), "PVD improvement combined with surcharge and vacuum preloading including simulations", Geotext. Geomembr., 29(1), 74-82.

Sathananthan, I. (2005), "Modelling of vertical drains with smear installed in soft clay", Ph.D. Thesis, University of Wollongong, Wollongong, Australia.

Sathananthan, I., Indraratna, B. and Rujikiatkamjorn, C. (2008), "Evaluation of smear zone extent surrounding mandrel driven vertical drains using the cavity expansion theory", Int. J. Geomech., 8(6), 355-365.

Sharma, J.S. and Xiao, D. (2000), "Characterization of a smear zone around vertical drains by large-scale laboratory tests",Can. Geotech. J., 37(6), 1265-1271.

Shin, D.H., Lee, C., Lee, J.S. and Lee, W. (2009), "Detection of smear zone using micro-cone and electrical resistance probe", Can. Geotech. J., 46(6), 719-726.

Stapelfeldt, T., Vepsäläinen, P. and Yin, Z.Y. (2009), "Numerical modelling of a test embankment on soft clay improved with vertical drains", Proceedings of the 2nd International Workshop on Geotechnics of Soft Soils, Glasgow, Scotland, September.

Tabatabaiefar, S., Fatahi, B. and Samali, B. (2013a), "Seismic behavior of building frames considering dynamic soil-structure interaction", Int. J. Geomech., 13(4), 409-420.

Tabatabaiefar, S., Fatahi, B. and Samali, B. (2013b), "Lateral seismic response of building frames considering dynamic soil-structure interaction effects", Struct. Eng. Mech., Int. J., 45(3), 311-321.

Tran-Nguyen, H.H. and Edil, T.B. (2011), "The characteristics of PVD smear zone", Proceedings of the Geo-Frontiers 2011: Advances in Geotechnical Engineering, New York, NY, USA, March.

Walker, R. and Indraratna, B. (2006), "Vertical drain consolidation with parabolic distribution of permeability in smear zone", J. Geotech. Geoenviron. Eng., 132(7), 937-941.

Walker, R. and Indraratna, B. and Rujikiatkamjorn, C. (2012), "Vertical drain consolidation with non-darcian flow and void-ratio-dependent compressibility and permeability", Géotechnique, 62(11), 985-997.

Yin, J.-H. and Graham, J. (1989), "Viscous-elastic-plastic modelling of one-dimensional time-dependent behaviour", Can. Geotech. J., 26(2), 199-209. 